Maria Teresa De Sibio

\title{
INFLUÊNCIA DO HORMÔNIO TIREOIDIANO E DA RESTRIÇÃO ALIMENTAR SOBRE DANO DE DNA EM ANIMAIS OBESOS
}

Dissertação apresentada ao Programa de Pós-Graduação "Fisiopatologia em Clínica Médica - Área de Concentração - Ciências da Saúde” da Faculdade de Medicina da Universidade Estadual Paulista "Júlio de Mesquita Filho", Câmpus de Botucatu, para a obtenção do título de Mestre.

Orientadora: Profa. Dra. Célia Regina Nogueira

BOTUCATU 
FICHA CATALOGRÁFICA ELABORADA PELA SEÇÃO TÉCNICA DE AQUISIÇÃO E TRATAMENTO DA INFORMAÇÃO

DIVISÃO TÉCNICA DE BIBLIOTECA E DOCUMENTAÇ̃̃O - CAMPUS DE BOTUCATU - UNESP BIBLIOTECÁRIA RESPONSÁVEL: Selma Maria de Jesus

Sibio, Maria Teresa.

Influencia do hormônio tireoidiano e da restrição alimentar sobre dano de DNA em animais obesos / Sibio Maria Teresa. - Botucatu: [s.n.], 2010.

Dissertação (mestrado) - Faculdade de Medicina de Botucatu, Universidade Estadual Paulista, 2010.

Orientadora: Célia Regina Nogueira

Assunto CAPES: 40603008

1. Hormônios tireoidianos - Efeitos fisiológicos 2. Obesidade 3. DNA

\section{CDD 616.44}

Palavras-chave: Dano de DNA; Hormônios tireoidianos; Obesidade; Restrição calórica 
Em memória da minha avó Thereza Stamponi, que deixou o nosso convívio durante o período do meu mestrado... Mas que está sempre viva em meu coração.

\begin{abstract}
Aos meus pais, Antonio Roberto e Maria Inês, referência para mim ao longo de toda minha existência, incentivadores e orgulhosos, pelo imenso e incondicional amor, constante estímulo, enorme dedicação, paciência, compreensão e pelas orações. Meu reconhecimento e eterna gratidão... sem vocês eu nada seria.
\end{abstract}

À minha irmã Paula, pelo incentivo em trilhar a área de Ciências Biológicas e exemplo de determinação.

Aos meus avos Abílio e Maria e meu Tio Claúdio que estiveram sempre presente e torcendo por mim obrigada por estarem sempre ao meu lado.

Ao Anderson meu namorado e companheiro, por compartilhar diariamente com paciência e compreensão a cada momento deste trabalho e situações difíceis das nossas vidas, sempre com muito amor. 
A DEUS, que em toda sua infinita grandeza e generosidade me deu meios e tornou apta a conduzir e concluir este trabalho, permitindo assim passar por mais essa etapa da minha vida.

À Dra. Célia Regina Nogueira pelo apoio, amizade e principalmente pela credibilidade com que me acolheu desde o início de minha carreira científica, me indicado as melhores direções, estando sempre disponível para ouvir e ajudar quando as dificuldades surgiam.

À Renata, uma mineirinha que tanto me aguentou nas horas de choro, e desespero nas alegrias e conquistas, por mais distante que estivesse sempre me ajudou muito... Nossa e quantos e-mails!! Muito Obrigada pelo companheirismo, dedicação, sinceridade nas palavras e atitudes, uma eterna amiga. Rê só você mesmo...

À Sueli Clara pelos preciosos momentos de aprendizado e alegria compartilhados. E não poderia esquecer... Saudações Tricolores!!

À Dra Camila Corrêa Camacho, que além de uma grande amiga me ajudou muito na realização da técnica Ensaio Cometa.

Ao Sandro Conde, um exemplo de sabedoria e um grande amigo, obrigada pela imprescindível ajuda desde minha Iniciação Científica e por participar em minha banca de qualificação.

Às minhas companheiras e amigas de laboratório, biotério, copa, das conversas, ajudas, desabafos, tristezas e de muitas alegrias Regiane, Miriane e Juliana se não fossem vocês tudo seria muito mais difícil, vocês tornaram essa jornada muito mais agradável e feliz. $\mathrm{E}$ muito obrigada por me escutarem umas 2.000x apresentando "que a obesidade ela é frequentemente considerada..." *rs.

Aos meus eternos amigos de Pós-Graduação, Aline (Moranguinho), Dijon, Marcelo e Ricardo, pelo companheirismo e convívio diário estando sempre dispostos a ajudarem nos pequenos ou grandes problemas decorrentes das atividades de pesquisa e emocionais.

Aos casais mais maravilhosos da experimental: André \& Renata; André Leopoldo \& Ana Paula; Paula \& Silvio, que tive o prazer de esbarrar nessa minha caminhada e que além de serem amigos de verdade e ajudaram diretamente nessa conquista.

Aos amigos do Laboratório Experimental da Clínica Médica: Adriana; Albano; Bonomo; Camila; Carol; Carol (Excedente); Carlos; Cris; Dani (Miga); Fábio; Fernanda; Luciana; Marcela; Natasha; Neide; Olga; Dra. Patrícia; Paulinha; Renata; Suflê (Mãe do Miguel); Rô e Yedda. 
Aos funcionários do Departamento e do Laboratório Experimental da Clínica Médica Alexandre Loureiro, Ana Mengue, Ângelo, Bruno Fajiolli, Bruno Silva, Corina Corrêa, Elenize Jamas, Elizangela Silva, José Aparecido de Souza (Boca), José Carlos Georgete (Zé), Mário Bruno, Renato Pereira, Rogério Monteiro, Sandra Fábio, Sueli Garcia, e as tias da limpeza sempre colocando o biotério em ordem depois de um dia de pesagem dos animais, todos sempre dispostos a ajudar no que fosse necessário.

Ao Prof. Dr. Carlos Roberto Padovani e ao Silvio Assis de Oliveira Júnior, pela ajuda nas análises estatísticas.

Ao Prof. Dr. Antônio Carlos Cicogna pelo apoio e sugestões.

À Dra Daisy Maria Favero Salvadori e suas orientadas Danielle, Elaine, Juliana e Mariana por ceder um espaço no laboratório (Incubadora Tecnológica na Fazenda Lageado) e pela fundamental ajuda.

À Dra Gláucia Mazeto e aos Residentes da Endócrino, pelas sugestões e estarem sempre disponível para ajudar no que fosse necessário.

À Dra Vânia dos Santos Nunes por ter participado nas bancas de qualificação e defesa, pelas ajudas e correções para que este trabalho pudesse ser finalizado.

À Dra Maria Tereza Nunes, que gentilmente aceitou participar e colaborar com este trabalho fazendo parte da Banca de Defesa.

Às queridas amigas de longa data, que não esquecerei jamais Amanda; Ana Paula; Ana Luísa; Aninha; Dany; Juliana; Larissa; Manuela; Valéria; Vanessa e Viviane. Obrigada pela amizade de vocês!

Aos amigos São Manuelenses: Fernanda \& André; Cecília \& Evandro; Erica \& Marco e Regina \& Osvaldo, que convertem todas as preocupações em alegria.

À Coordenação de Aperfeiçoamento de Pessoal de Nível Superior (CAPES) pela concessão da bolsa de mestrado.

De uma maneira geral gostaria de agradecer todas as pessoas que de alguma forma participaram de alguma das etapas para a realização deste trabalho. Muitas vezes um simples gesto pode mudar a nossa vida e contribuir para o nosso sucesso. A vocês, que pude dividir um trecho da minha caminhada e aprendi um pouco com cada um, que o que importa não é o resultado final, mas as conquistas realizadas durante o caminho e a marca que deixamos e que as pessoas deixam. 
"Deus nos fez perfeitos e não escolhe os capacitados, capacita os escolhidos. Fazer ou não fazer depende de nossa vontade $\mathrm{e}$ perseverança" 
Introdução: A obesidade é uma doença crônica, multifatorial que leva ao aumento do risco de desenvolver outras doenças. É freqüentemente considerada como uma doença do estilo de vida, causada pela escolha errônea dos alimentos e pela diminuição da atividade física, sendo a restrição calórica a prática mais comum para tratar a obesidade. $O$ aumento da ingestão de calorias ou dieta rica em gordura são determinantes significativos do dano de ácido desoxirribonucléico (DNA). Vários estudos mostraram que o dano de DNA diminui em animais submetidos à restrição calórica, por diminuir a formação de radicais livres. Concentrações fisiológicas de hormônios tireoidianos não produzem danos genéticos. Por outro lado concentrações inadequadas desses hormônios podem gerar danos de DNA. Objetivo: Verificar a interação entre obesidade, dose suprafisiológica de hormônio tireoidiano e restrição alimentar sobre o dano de DNA.

Metodologia: Foram utilizados ratos Wistar machos, com 30 dias de idade, provenientes do Biotério Central da UNESP de Botucatu. Os animais foram separados em dois grupos, Controle (C) e Obeso (OB). Os animais do grupo controle receberam ração comercial padrão enquanto o grupo obeso foi submetido a um processo de indução de obesidade e recebeu dieta hipercalórica que foram padronizadas pela empresa Agroceres $^{\circledR}$, por 20 semanas. Posteriormente, 20 animais do grupo $\mathrm{OB}$ foram submetidos à restrição alimentar $(\mathrm{RC})$ e receberam $75 \%$ da quantidade consumida pelo grupo $C$ de dieta padrão, por 8 semanas, enquanto os demais continuaram recebendo as dietas hipercalóricas até o final do experimento. Assim, a restrição aplicada a esses grupos foi de $25 \%$. Após este período, 10 animais do grupo $\mathrm{RC}$ continuaram sob restrição alimentar, enquanto os 10 restantes, além da restrição, receberam dose suprafisiológica de HT (RCS) de $25 \mu \mathrm{g} / 100 \mathrm{~g}$ de peso do animal e o mesmo ocorreu no grupo obeso, onde 10 animais do grupo OB continuaram recebendo dieta hipercalórica, enquanto os 10 restantes, além da dieta hipercalórica, receberam dose suprafisiológica de HT (RCS) de $25 \mu \mathrm{g} / 100 \mathrm{~g}$ de peso do animal, durante 2 semanas. Ao final do experimento 10 animais de cada grupo foram eutanasiados. A eutanásia dos animais foi necessária 
para a realização dos exames bioquímicos, das dosagens hormonais e ensaio cometa.

Resultados: Os animais OB apresentaram aumento de peso, adiposidade e dano de DNA, alterações no perfil lipídico e glicêmico, aumento de leptina e insulina plasmáticas e diminuição no sistema reparo, enquanto o grupo OBS tratado com $T_{3}$ apresentou aumento no dano de DNA e diminuição do sistema reparo, quando comparados aos animais OB. Os animais RC apresentaram diminuição de peso, adiposidade e dano no DNA e aumentou o sistema reparo, melhoraram o perfil lipídico e glicêmico e normalizaram os níveis de leptina e insulina, sendo similares ao grupo $C$. enquanto o grupo RCS tratado com $T_{3}$ apresentaram aumento nos danos de DNA e diminuição do sistema reparo, quando comparados aos animais $\mathrm{RC}$.

Conclusão: A dieta utilizada neste estudo, rica em AGI, ocasionou obesidade e provocou dano de DNA. A dose supra fisiológica de $T_{3}$, administrada em animais $\mathrm{OB}$, reduziu o peso corporal e a adiposidade, entretanto potencializou a produção de dano de DNA nestes animais. A restrição alimentar minimizou os efeitos da obesidade, diminuindo peso, adiposidade e as lesões de DNA no grupo tratado com salina. Contudo, não foi eficiente em reduzir os danos causados pela administração de triiodotironina, mostrando que o hormônio tireoidiano em altas doses leva a lesão de DNA independente do tratamento. 
Introduction: Obesity is a chronic and multifactorial disease which increases the risk of developing other health conditions. It is usually considered a disease related to a lifestyle in which a wrong diet is chosen and no physical activity is carried out. The most common practice to treat obesity is caloric restriction. The increase in calories intake and a diet rich in fat are significant determinants to Deoxyribonucleic Acid (DNA) damage. Several studies have shown that the DNA damage decreases in animals submitted to caloric restriction because such restriction reduces the free radicals formation. Physiological concentrations of thyroid hormones do not produce genetic damages. On the other hand, inappropriate concentrations of such hormones can cause DNA damage.

Objective: To verify the interaction between obesity, supraphysiological dose of thyroid hormone and food restriction on DNA damage.

Methodology: Male Wistar rats, with 30 days of age supplied by São Paulo State University Animal Centre Universidade Estadual Paulista (UNESP), Botucatu, SP. Brazil were divided into two groups: Control $(\mathrm{C})$ and Obese (OB). The control group were fed on either a normal diet, while obese group was submitted to a process of obesity induction and received a hypercaloric diet, standardized by Agroceres ${ }^{\circledR}$, during 20 weeks. Later, 20 animals in $\mathrm{OB}$ group were submitted to food restriction $(\mathrm{RC})$ receiving $75 \%$ of the amount eaten by the $\mathrm{C}$ group, with standard diet, during eight weeks, while remaining rats continuously received the hypercaloric diet until the end of the experiment. Hence, these groups had a food restriction of $25 \%$. After this period, 10 animals in RC group were maintained in food restriction while 10 remaining animals, besides food restriction, also received a supraphysiological dose of HT (RCS) of $25 \mu \mathrm{g} / 100 \mathrm{~g}$ of animal body weight. The same procedure was carried out in OB group, where 10 animals continuously received a hypercaloric diet while 10 remaining animals, besides hypercaloric diet, also received a supraphysiological dose of $\mathrm{HT}$ (RCS) of $25 \mu \mathrm{g} / 100 \mathrm{~g}$ of animal body weight, during two weeks. At the end of the experiment, 10 animals in each group suffered euthanasia. The euthanasia was carried out in order to biochemical exams, hormonal levels and Single Cell Gel Electrophoresis could be accomplished. 
Results: Animals in OB group presented weight gain, adiposity, DNA damage, alterations in lipidic and glicemic profiles, increase in leptin and plasmatic insulin and decrease in repair system, while the OBS group, treated with $T_{3}$ presented an increase in DNA damage and a decrease in repair system when compared to animals in $\mathrm{OB}$ group. The animals in $\mathrm{RC}$ group presented weight loss, adiposity, DNA damage, increase in repair system, improved lipidic and glicemic profiles and normal levels of leptin and insulin, with values similar to $C$ group. The RCS group, treated with $T_{3}$, presented increase in DNA damage and decrease in repair system, when compared to $\mathrm{RC}$ group.

Conclusion: The diet adopted in this study, rich in AGl, caused obesity and induced DNA damage. The supraphysiological dose of $T_{3}$, provided to $O B$ group reduced body weight and adiposity, but highlighted the production of DNA damage. The food restriction minimized the effects of obesity, decreasing weight, adiposity and DNA damages in the group treated with saline solution. However, it was not efficient in reducing the damages caused by the administration of triiodotironina, showing that the thyroid hormone in high levels leads to DNA damage, independently the treatment. 
Figura 1: Delineamento do estudo 10

Figura 2: Caracterização dos grupos 12

Figura 3: Critério de exclusão 15

Figura 4: Delineamento do estudo após caracterização dos grupos 16

Figura 5: Evolução semanal do peso corporal 17

Figura 6: Quantificação da gordura total. 20

Figura 7: Índice de Adiposidade. 21

Figura 8: Índice de Lee. 22

Figura 9: Concentração sérica de insulina. 25

Figura 10: Concentração sérica de leptina. 26

Figura 11: Concentração sérica de triiodotironina (T3 livre) 27

Figura 12: Concentração sérica de tiroxina (T4 livre). 28

Figura 13: Concentração sérica de hormônio estimulador da tireóide (TSH) 29

Figura 14: Porcentagem de dano de DNA 30

Figura 15: Dano de DNA induzido por $\mathrm{H}_{2} \mathrm{O}_{2}$ 31

Figura 16: Sistema Reparo 32 
Tabela 1: Valor nutricional das dietas hipercalóricas.

Tabela 2: Características morfométricas.

Tabela 3: Características nutricionais. 19

Tabela 4: Análise bioquímica. 23

Tabela 5: Área sob a curva glicêmica e razão insulina/glicose plasmática. 24 
ACC Área sob a curva glicêmica

ANOVA Análise de Variância

C. Grupo Controle

CNA Comprimento naso-anal

Col .Colesterol Total

DNA Ácido desoxirribonucléico

E.A. Eficiência Alimentar

Eros Espécies reativas de oxigênio GCT Gordura Corporal Total $\mathrm{H}_{2} \mathrm{O}_{2}$ Peróxido de hidrogênio ou Água Oxigenada HDL Lipoproteína de alta densidade HT Hormônio Tireoidiano IBGE Instituto Brasileiro de Geografia e Estatística Ins/Gli Razão insulina/glicose plasmática ITT Teste de Tolerância à Insulina

LDL Lipoproteína de baixa densidade $\mathrm{OB}$. Grupo Obeso

OBS .Grupo Obeso com dose Suprafisiológica de $T_{3}$

OMS Organização Mundial de Saúde PCF Peso Corporal Final $\mathrm{PCl}$ .Peso Corporal Inicial $\mathrm{T}_{3}$ Triiodotironina $\mathrm{T}_{4}$ Tiroxina TG. .Triacilglicerol TRH Hormônio Liberador de Tireotrofina TSH. Hormônio Estimulador da Tireóide $\mathrm{RC}$ Grupo com Restrição Calórica RCS Grupo com Restrição Calórica e dose Suprafisiológica de $T_{3}$ 


\section{SUMÁRIO}

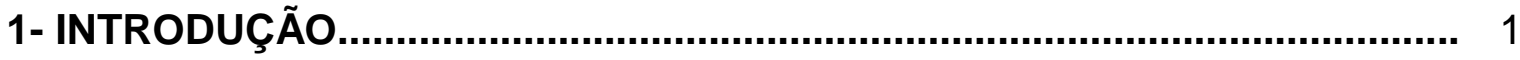

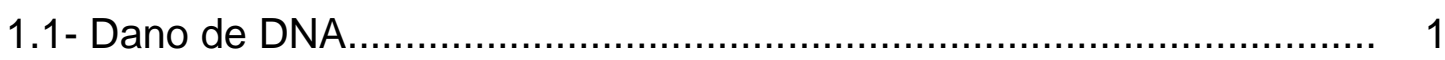

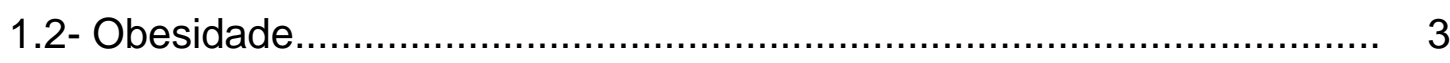

1.3- Restrição Alimentar.......................................................................... 4

1.4- Hormônios Tireoidianos................................................................... 5

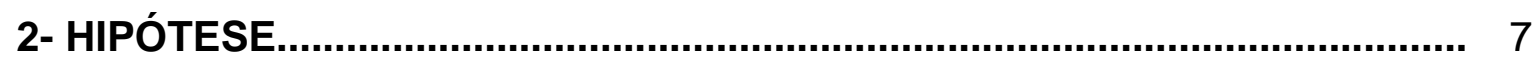

3- OBJETIVO GERAL............................................................................. 8

3.1- Objetivos Específicos................................................................. 8

4- MATERIAL E MÉTODOS....................................................................... 9

4.1- Protocolo Experimental................................................................. 9

4.2-Composição das Dietas ............................................................... 10

4.3- Caracterização dos Grupos........................................................... 11

4.4- Teste de Tolerância à Insulina....................................................... 12

4.5- Depósitos de Gordura Corporal.......................................................... 12

4.6- Eficiência Alimentar e Ingestão Calórica............................................. 13

4.7- Análise Bioquímica...................................................................... 13

4.8- Dosagens Hormonais................................................................... 13

4.9- Ensaio Cometa........................................................................... 13

4.10- Análise Estatística....................................................................... 14

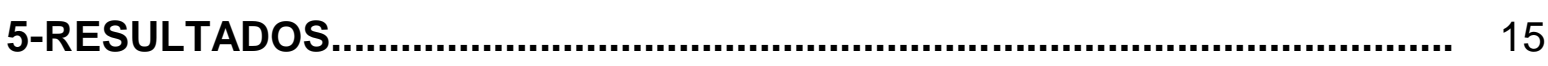

5.1-Constituição dos Grupos.............................................................. 15

5.2- Caracterização dos grupos........................................................... 16

5.2.1-Evolução do Peso.................................................................... 16

5.3 - Análise Bioquímica...................................................................... 22

5.4- Teste de Tolerância à Insulina............................................................ 23

5.5- Dosagens Hormonais................................................................. 24

5.6- Ensaio Cometa........................................................................... 29

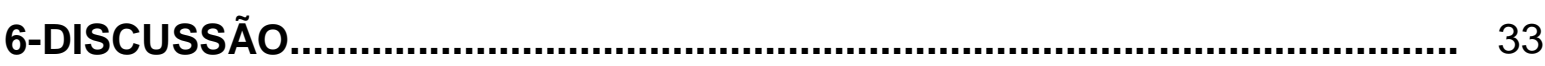

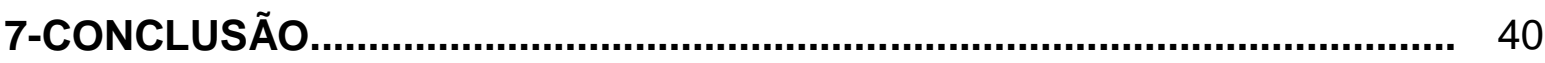

8- REFERÊNCIAS BIBLIOGRÁFICAS......................................................... 41

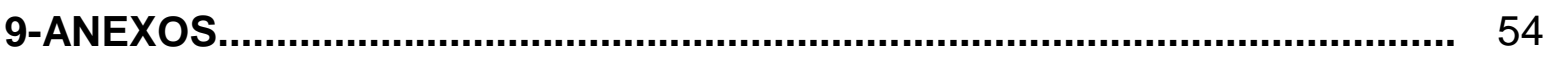




\section{1- INTRODUÇÃO}

\section{1- Dano de DNA}

O ácido desoxirribonucléico (DNA) não é uma molécula estável e frequentemente está exposto a diversos agentes naturais ou artificiais, que podem provocar-Ihe danos (BERNSTEIN \& BERNSTEIN, 1991). Em condições normais, cerca de $99 \%$ dos danos do DNA podem ser reparados, mas aproximadamente $1 \%$ podem permanecer no genoma da célula (FREI, 1994). Os danos ao DNA não reparados podem resultar em perda de informação genética ou interferência na transcrição e replicação, portanto, tais danos podem ser deletérios e frequentemente letais (BERNSTEIN \& BERNSTEIN, 1991).

Segundo Ames (1989), existem quatro processos endógenos que, possivelmente, são de maior importância para a ocorrência de danos de DNA: a) oxidação (Totter, 1980; Ames, 1983); b) metilação; c) desaminação; e d) depurinação (SAUL E AMES, 1986). A importância desses processos é indicada pela existências de enzimas de reparo específicas para corrigir tais danos (AMES, 1989).

Os danos oxidativos no DNA são provavelmente os de maior relevância e estão positivamente correlacionados com a taxa metabólica (AMES, 1989).

Halliwell \& Gutteridge (1999) definiram o estresse oxidativo como o desequilíbrio no balanço entre agentes pró-oxidantes e agentes antioxidantes com a potencialidade de exercer efeitos deletérios. $O$ estresse oxidativo tem potencial de danificar macromoléculas tais como DNA, lipídios e proteínas. Para combater este estresse oxidativo existe o sistema de defesa antioxidante, do qual participam enzimas e outros compostos de natureza não-enzimática (STOREY, 1996).

Atualmente, existe um grande interesse no estudo dos antioxidantes devido às descobertas sobre o efeito das espécies reativas no organismo. A oxidação é parte fundamental da vida aeróbica e do metabolismo, assim, as espécies reativas de oxigênio (EROs) são produzidas naturalmente ou por alguma disfunção biológica (CERUTTI, 1994).

O dano oxidativo produzido por EROs acumula-se com o tempo, levando ao desenvolvimento de doenças como o câncer. EROs são bioprodutos do metabolismo 
energético, que atacam lipídios, proteínas e DNA, gerando um número de produtos que afetam a função de células normais (HALLIWELL, 1999).

Essas espécies podem ser geradas durante o processo endógeno fisiológico e patológico, e também podem ser geradas por fontes exógenas como: substâncias presentes nos alimentos, fármacos, poluição, fumo, álcool, entre outras (HALLIWELL, 1994; ARUOMA, 1994).

O DNA lesado sem reparação leva à apoptose ou mutação e a presença de mutação pode levar à carcinogênese. Vários sistemas celulares e moleculares, respondem a estes danos (HOEIJIMAKERS, 2001). A apoptose está associada ao aumento do dano de DNA e/ou prejuízo do sistema de reparo (FORTINI, 2003).

Danos no DNA são diferentes de mutações. Enquanto a mutação é ligada a uma variação na sequência de polinucleotídeos, os danos são devido a uma alteração física na estrutura da cadeia de polinucleotídeos. Os danos não podem ser replicados e, consequentemente, não podem ser herdados, enquanto a mutação não impede a transcrição ou replicação. (BERNSTEIN \& BERNSTEIN, 1991).

Outro aspecto que difere os danos no DNA de mutações é o fato de que a estrutura alterada pode ser reconhecida por enzimas de reparo e, consequentemente, os danos no DNA podem ser corrigidos. As mutações não são reparadas, pois possuem estruturas regulares, não sendo reconhecidas pelas enzimas do sistema reparo (BERNSTEIN \& BERNSTEIN, 1991).

Contudo, um aspecto de grande importância é que alguns estudos comprovaram o fato de que danos no DNA induzem mutações (King, 1994; Terzoudi e Pantelias, 1997) e que, na espécie humana a instabilidade genética pode estar ligada a várias doenças, entre elas o câncer (HIGGINSON, 1998; AMES, 1983, 1989).

Danos no DNA resultantes do modo de vida e de outras influências ambientais são responsáveis por cerca de $80 \%$ a $90 \%$ dos cânceres humanos (DOLL \& PETO, 1981).

O alto índice de neoplasias de que sofre a sociedade atual reflete a mudança nos hábitos alimentares que ocorreu com a era tecnológica. Tazima et al. (1984) sugeriram a existência de centenas de mutagênicos na comida, alguns naturalmente presentes e outros que podem ter se desenvolvido durante o processamento alimentar (JAIN, 1987). 
Segundo Jain (1987), o risco da carcinogênese é devido não somente à presença de agentes genotóxicos, mas também à falta de agentes antimutagênicos e anticarcinogênicos em dietas deficientes.

\section{2- Obesidade}

A obesidade é uma doença metabólica crônica caracterizada pelo acúmulo excessivo de tecido adiposo em relação à massa magra tecidual. É considerada uma epidemia global e um importante problema de saúde pública, que afeta tanto países desenvolvidos quanto os países em desenvolvimento (O'BRIEN, 2002).

Esta doença também é um problema de saúde pública, sendo uma carga para o sistema de saúde e para a sociedade. Atualmente, mais de $30 \%$ dos adultos americanos e $70 \%$ - $80 \%$ dos pacientes com Diabetes Mellitus tipo 2 são obesos (LONNQVIST, 1999).

De acordo com a Organização Mundial de Saúde (OMS) "a obesidade está se tornando um dos mais importantes males da saúde" onde mais de um bilhão de adultos apresentam sobrepeso e, aproximadamente, 300 milhões são obesos. No Brasil, de acordo com a Pesquisa de Orçamentos Familiares do Instituto Brasileiro de Geografia e Estatística (IBGE), cerca de 40 milhões de pessoas estão acima do peso ideal e destes 10,5 milhões são obesos.

A obesidade é uma doença crônica caracterizada por hipertrofia e hiperplasia de células de gordura levando ao aumento do risco de desenvolver Diabetes Mellitus tipo 2, doenças cardíacas, hipertensão, arteriosclerose e outras desordens. Não se sabe se o estímulo para aumento do número de células adiposas é nutricional, endócrino, comportamental, genético ou alguma combinação desses fatores (BELLANDERSON, 2004).

A causa básica da obesidade é multifatorial e, provavelmente, é uma combinação entre genética, meio ambiente e fatores psicossociais que determinam o balanço entre a ingestão alimentar e o gasto energético (BELL-ANDERSON, 2004).

O aumento da ingestão de calorias ou dieta rica em gordura são determinantes significativos do dano de ácido desoxirribonucléico (DNA) (PARKS, 2001; HENNING, 2001). Esse aumento na ingestão de calorias aumenta significativamente a geração de EROs (LOPEZ-TORRES, 2002). 
Lili et al., 2006, encontraram dano de DNA aumentado e sistema de reparo diminuído nos camundongos ob/ob quando comparados aos normais. Em concordância Dermibag e cols, 2004 mostraram correlação positiva entre dano de DNA e hiperlipidemia.

Estudo que avaliou dano de DNA em músculo esquelético de indivíduos jovens saudáveis não obesos mostrou que os que reportaram ganho de peso, por volta de $7 \mathrm{~kg}$ em 10 anos, apresentaram maior dano de DNA quando comparados aos que mantiveram o peso estável (MAZA, 2006).

\section{3- Restrição Alimentar}

As dietas hipocalóricas são comumente usadas para tratar a obesidade e têm papel central na redução de gordura em indivíduos obesos (DAHLMAN et al., 2005).

Os princípios do controle do peso em indivíduos com sobrepeso e obesidade são atingir uma perda de peso clinicamente significante (FINER, 2001). O "National Institutes of Health" sugere redução de $10 \%$ do peso como objetivo inicial. Uma perda de 5 a $10 \%$ do peso tem mostrado reduzir o risco de doença cardíaca (STRYCHAR, 2006).

Para a perda de peso, as estratégias mais utilizadas são a redução da ingestão calórica e o aumento da atividade física (WEISS et al., 2006). Pesquisas concluíram que programas combinando ambos os comportamentos são geralmente mais efetivos em reduzir peso do que apenas um deles (DUNN et al., 2006).

Sabe-se que a restrição alimentar retarda o acúmulo celular de moléculas oxidativamente danosas que atenuam o aumento da peroxidação lipídica associada com o processo de envelhecimento, o acúmulo de proteínas oxidadas e dano oxidativo no DNA (WANAGAT et al., 1999).

Vários estudos mostraram que 0 dano de DNA diminui em animais submetidos à restrição alimentar (GREDILLA, 2001; ZAINAL, 2000; BARJA, 2004). A restrição reduz o dano de DNA por diminuir a formação de radicais livres (STUART, 2004).

Um estudo recente mostrou que o efeito benéfico da restrição calórica em roedores pode ocorrer apenas se a restrição tiver início precoce na vida desses animais (FORSTER, 2003). Em contraste, outro estudo indicou que a restrição na meia idade ainda é benéfica (TAKAHASHI \& GOTO, 2002). Sanz e cols, 2005 
sugerem ainda que a restrição pode ser benéfica mesmo em animais mais velhos, porque ela diminui o estresse oxidativo e mitocondrial e o dano oxidativo.

\section{4- Hormônios Tireoidianos}

Os hormônios tireoidianos estão essencialmente envolvidos na regulação do gasto energético e na termogênese, e a disfunção tireoidiana é frequentemente associada com mudanças no apetite e peso corporal (KAUTZKY-WILLER et al., 1999).

Os dados da literatura são conflitantes a respeito da relação entre função tireoidiana e o peso corporal. Näslund et al., 2000 demonstrou níveis altos, outros baixos e outros similares em indivíduos obesos comparados com indivíduos de peso normal.

O Hormônio Estimulador da Tireóide (TSH) e os hormônios tireoidianos periféricos Triiodotironina $\left(T_{3}\right)$ e Tiroxina $\left(T_{4}\right)$ estão aumentados na obesidade. A causa desse aumento não está clara. O aumento na concentração dos hormônios tireoidianos pode indicar uma resistência hormonal, parecida com a resistência à insulina que ocorre na obesidade. Em suporte para esta teoria está o fato de que, na obesidade, receptores $\mathrm{T}_{3}$ estão diminuídos e o feedback negativo entre $\mathrm{TSH}, \mathrm{T}_{3}$ e $\mathrm{T}_{4}$ também está diminuído (REINEHR, 2002).

A atividade da tireóide cai em restrição calórica, levando à redução do gasto energético (PINKNEY, 1998).

Segundo Kim et al., 2000, a inanição está associada à depressão do eixo hipotálamo - hipófise - tireóide. Sendo assim, T3, T4, TSH e TRH estão reduzidos em humanos durante a restrição alimentar.

Concentrações fisiológicas de hormônios tireoidianos não produzem danos genéticos. Por outro lado, concentrações inadequadas desses hormônios podem gerar danos de DNA (HUDIG, 1997). Estudo realizado em cultura celular tratada com $\mathrm{T}_{3}$, mostrou que o hormônio tireoidiano aumenta a taxa metabólica e o consumo de oxigênio gerando estresse oxidativo, induzindo dano de DNA (DJELIC, 2003).

Os homônimos tireoidianos aumentam a atividade metabólica em quase todos os tecidos do corpo. O consumo mitocondrial de oxigênio aumenta no hipertireoidismo, sugerindo que quantidade excessiva de EROs podem ser geradas e a geração de água oxigenada $\left(\mathrm{H}_{2} \mathrm{O}_{2}\right)$ pode ser subsequentemente aumentada no 
hipertireoidismo (TURRENS, 1985). Em concordância, Magsino e cols, 2000 mostraram que administração suprafisiológica de $T_{3}$ por sete dias induziu aumento na geração de EROs, levando a dano de DNA.

Está bem definido que obesidade, restrição alimentar e os hormônios tireoidianos, isoladamente, influenciam a geração de danos de DNA (HENNING, 2001; BARJA, 2004; HUDIG, 1997).

Não se sabe se a associação entre obesidade, restrição calórica e administração de hormônio tireoideano podem levar a diferentes respostas. Assim, foi proposto um modelo experimental de restrição alimentar após obesidade e administração de hormônios tireoidianos para analisar estas associações. 


\section{2- HIPÓTESE}

Como a obesidade e doses suprafisiológicas de hormônio tireoidiano, isoladamente, promovem lesão de DNA, a associação entre estes fatores podem potencializar o dano. Uma vez que a restrição alimentar minimiza o dano de DNA, por meio da diminuição do estresse oxidativo, especula-se que as lesões causadas pela administração de HT possam ser atenuadas em associação à restrição alimentar. 


\section{3- OBJETIVO GERAL}

Verificar a interação entre obesidade, dose suprafisiológica de hormônio tireoidiano e restrição alimentar sobre o dano de DNA.

\section{1- Objetivos específicos}

Verificar a relação entre obesidade induzida por Ácidos Graxos Insaturados e dano de DNA.

Verificar a relação entre restrição Calórica após obesidade induzida por Ácidos Graxos Insaturados.

Verificar a relação entre Hormônio Tireoidiano, Restrição Calórica e Dano de DNA. 


\section{4- MATERIAL E MÉTODOS}

\section{1- Protocolo Experimental}

O protocolo experimental foi aprovado pela Comissão de Ética em Experimentação Animal da Faculdade de Medicina de Botucatu - UNESP (anexo 01), estando de acordo com o "Guia para Cuidados e Usos de Animais Experimentais".

Para este trabalho foram utilizados 70 ratos da raça Wistar, machos, com 30 dias de idade e pesando aproximadamente $150 \mathrm{~g}$, provenientes do Biotério Central da UNESP de Botucatu. Os animais foram separados, aleatoriamente, primeiramente em dois grupos: Controle (C) com 15 animais e Obeso (OB) com 55 animais. O grupo controle recebeu ração comercial padrão enquanto o grupo obeso foi submetido a um processo de indução de obesidade e recebeu ração hipercalórica que foram padronizadas pela empresa Agroceres ${ }^{\circledR}$, por 20 semanas. Posteriormente, 20 animais do grupo $\mathrm{OB}$ foram submetidos à restrição calórica $(\mathrm{RC})$ e receberam $75 \%$ da quantidade consumida pelo grupo C de dieta padrão, por 8 semanas, enquanto os demais continuaram recebendo as dietas hipercalóricas. Assim, a restrição aplicada a esses grupos foi de 25\% (FERNÁNDEZ-GALAZ, 2002). Após este período, 10 animais do grupo OB continuaram recebendo dieta hipercalórica, enquanto os 10 restantes, além da dieta hipercalórica, receberam dose suprafisiológica de HT (RCS) de 25 $\mathrm{g} / 100 \mathrm{~g}$ (Giannocco, 2004) de peso do animal, o mesmo ocorreu com o grupo RC, onde 10 animais do grupo $\mathrm{RC}$ continuaram sob restrição alimentar, enquanto os 10 restantes, além da restrição, receberam dose suprafisiológica de HT (RCS) de $25 \mu \mathrm{g} / 100 \mathrm{~g}$ de peso do animal, durante 2 semanas, como delineado na Figura 1.

Ao final do experimento 10 animais de cada grupo foram eutanasiados. A eutanásia dos animais foi necessária para a realização dos exames bioquímicos, das dosagens hormonais e ensaio cometa.

O consumo da dieta foi controlado diariamente e o peso corporal dos ratos aferido semanalmente, utilizando-se uma balança digital Mettler ${ }^{\circledR}$ modelo Spider 2. Durante o trabalho, os animais foram mantidos em gaiolas de polipropileno individuais forradas com maravalha de Pinus esterilizada, com tampa de arame 
cromado, em ambiente com temperatura $\left(22-26^{\circ} \mathrm{C}\right)$ e luminosidade (ciclo claro escuro - 12h) controladas.

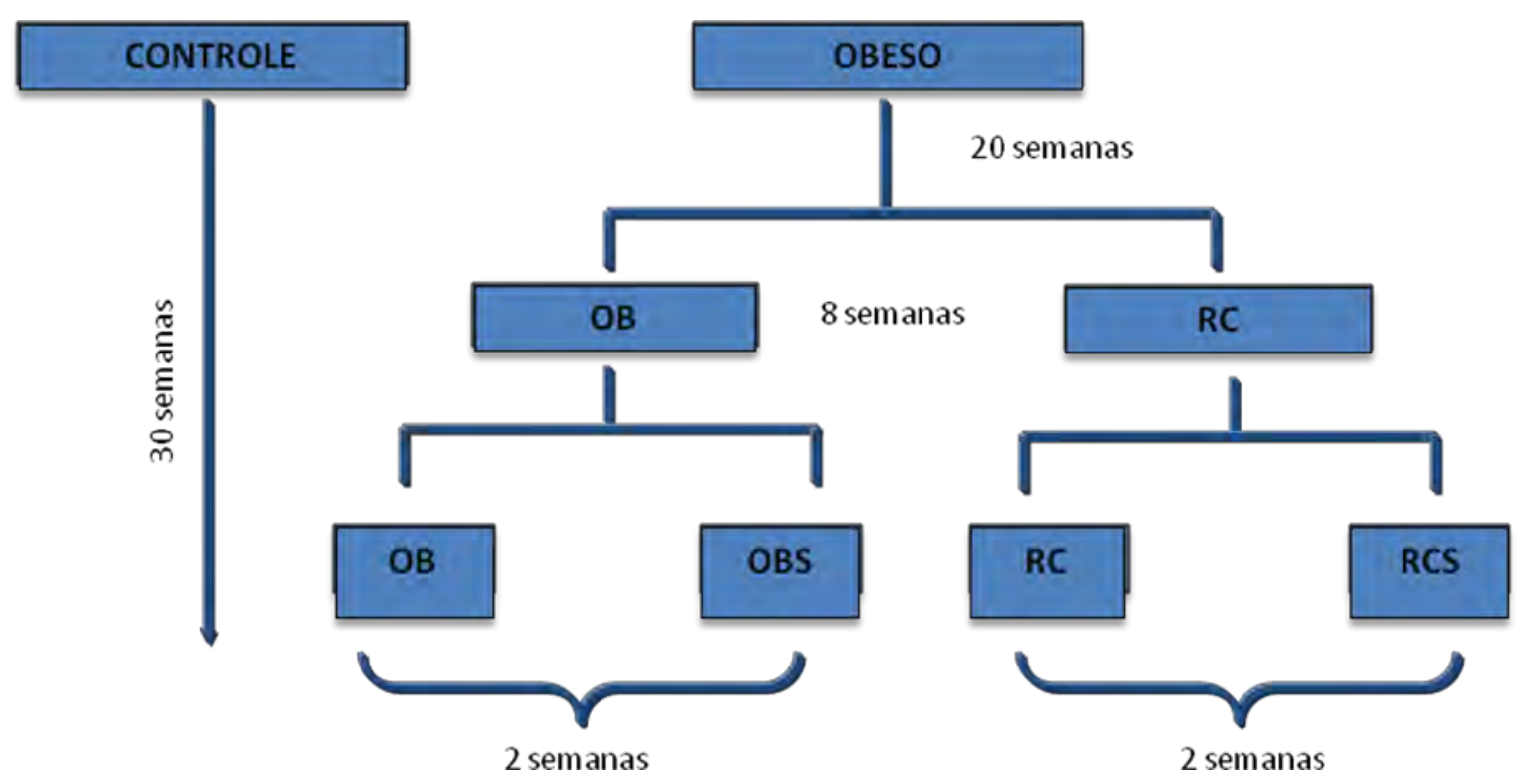

Figura 1- Delineamento do estudo. C, controle; $\mathrm{OB}$, obeso; $\mathrm{RC}$, restrição calórica, $\mathrm{OBS}$, obeso com dose de triiodotironina na concentração de $25 \mu \mathrm{g} / 100 \mathrm{~g}$ de peso; RCS, restrição com dose de triiodotironina na concentração de $25 \mu \mathrm{g} / 100 \mathrm{~g}$ de peso.

\section{2- Composição das Dietas}

As dietas experimentais seguiram as especificações do guia "Nutrient requirements of the laboratory rat" para ratos de laboratório. A dieta base de todo o processo é a ração comercial da Agroceres - Nutrição Animal, fabricada em Rio Claro, SP, Brasil. Essa ração é constituída de 4\% de gordura; 22\% de proteína; $51,5 \%$ de carboidrato; $7 \%$ de cinzas; $4,5 \%$ de matéria fibrosa e $11 \%$ de umidade.

Durante a indução de obesidade foram utilizadas quatro dietas hiperlipídicas por excesso de ácidos graxos insaturados, foram padronizadas pela empresa Agroceres $^{\circledR}$ Nutrição Animal, Rio Claro, SP, Brasil, que consistem dos mesmos componentes, porém aromatizadas com essências diferentes (chocolate, queijo, bacon e baunilha). As dietas são compostas por cloreto de sódio, caseína, soro de leite em pó, concentrado protéico de soja, milho integral moído, farinha de bolacha, fosfato bicálcico, carbonato de cálcio, aditivo emulsificante, óleo de milho, aditivo 
antioxidante, premix mineral vitamínico e aromatizante. Durante o experimento os animais OB e OBS receberam essa dieta, que foi alternada diariamente entre um aroma doce e um salgado. A tabela 1 apresenta 0 valor nutricional das dietas oferecidas aos animais.

Esse modelo experimental de obesidade foi padronizado e validado pelo Laboratório Experimental da Clínica Médica - Faculdade de Medicina - UNESP Botucatu (NASCIMENTO, 2008).

Tabela 1: Valor nutricional das dietas hipercalóricas

\begin{tabular}{lcc}
\hline & Garantidos & Típicos \\
\hline Umidade (máx.) & $12,5 \%$ & $10,0 \%$ \\
Proteína Bruta (mín.) & $20 \%$ & $20 \%$ \\
Gordura (min) & $20 \%$ & $20 \%$ \\
Carboidrato (min) & $34 \%$ & $34 \%$ \\
Matéria fibrosa (máx.) & $9 \%$ & $6 \%$ \\
Matéria Mineral (máx.) & $10 \%$ & $10 \%$ \\
Cálcio (máx.) & $1,4 \%$ & $1,0 \%$ \\
Fósforo (mín.) & $0,70 \%$ & $0,70 \%$
\end{tabular}

Para cada 1000g de dieta serão acrescentados: ferro: $50 \mathrm{mg}$; zinco: $60 \mathrm{mg}$; cobre: $10 \mathrm{mg}$; iodo $2 \mathrm{mg}$; manganês: $60 \mathrm{mcg}$; vitamina $\mathrm{B} 1: 5 \mathrm{mg}$; vitamina $\mathrm{B} 2: 6 \mathrm{mg}$; vitamina $\mathrm{B} 6: 7 \mathrm{mg}$; vitamina B12: $20 \mathrm{mcg}$ niacina: $60 \mathrm{mg}$; biotina: $0,05 \mathrm{mg}$; colina: $600 \mathrm{mg}$; ácido pantotênico: $20 \mathrm{mg}$, ácido fólico: $1 \mathrm{mg}$; vitamina E: 30mg; vitamina D: 1800 UI; vitamina A: 12000 UI; vitamina K: 3mg; antioxidante: 100mg.

\section{3- Caracterização dos Grupos}

Para caracterizar os grupos $\mathrm{C}$ e $\mathrm{OB}$ foi utilizado um critério estatístico para peso corporal final (PCF), pelo qual foi estabelecido um intervalo de confiança (IC) de $95 \%$ para ambos os grupos. Foi adotado como ponto de separação (PS) entre os grupos o ponto médio entre o limite superior do controle e o limite inferior do obeso, sendo excluídos do grupo controle os animais com peso corporal acima do PS e do grupo obeso os animais com peso corporal abaixo do PS.

O grupo C foi utilizado, principalmente, para caracterização da obesidade, mas também como referência para restrição calórica e, por isso, continuou até o final do experimento. 


\section{PESO CORPORAL FINAL}

\section{Intervalo de confiança}

\section{Controle}
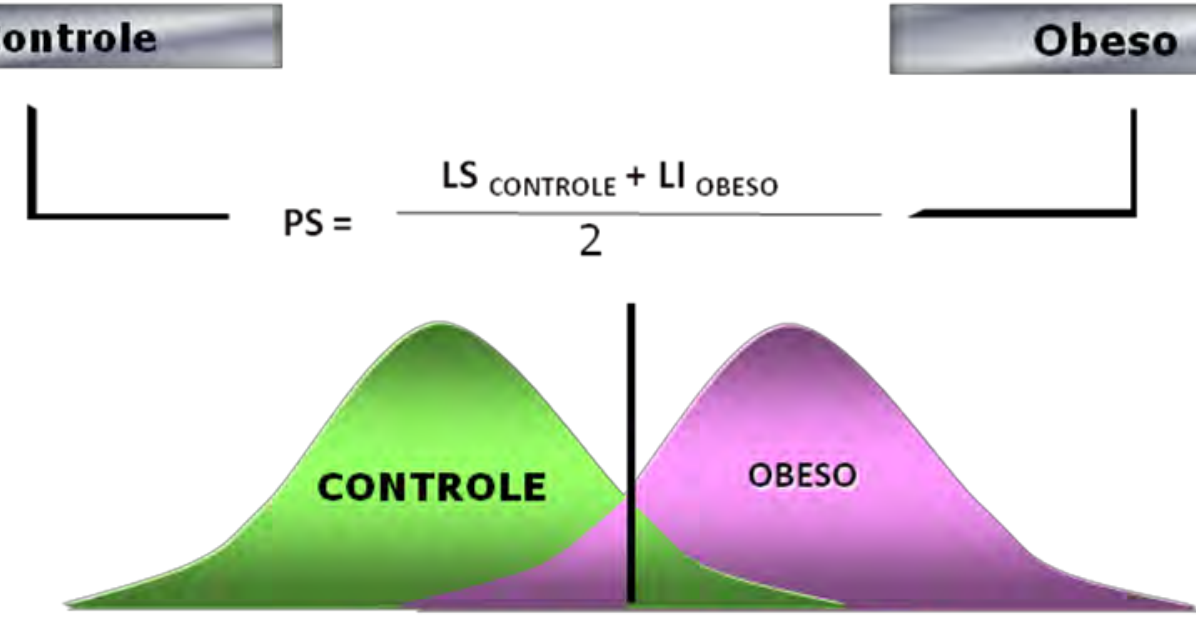

\section{Ponto de Separação (PS)}

Figura 2- Caracterização dos grupos: Critério de exclusão pelo Peso corporal final.

\section{4- Teste de Tolerância à Insulina}

Para avaliar a sensibilidade à insulina foi realizado o teste de tolerância à insulina (ITT). Os animais foram submetidos a jejum de 4 a 6 horas e a insulina (1U/kg - Novolin R) foi administrada por injeção intraperitoneal. Os níveis de glicose sanguínea foram mensurados nos momentos basal (antes da administração da insulina), 05, 10, 15, 20, 25 e 30 minutos após a administração da insulina (CLARET, 2004).

\section{5- Depósitos de Gordura Corporal}

A gordura corporal total (GCT) foi mensurada pela soma dos depósitos de gordura epididimal, retroperitoneal e visceral (LEVIN, 2002). Este dado foi utilizado para confirmar a obesidade nos animais. Além disso, o Índice de Lee (raiz cúbica do peso corporal final (gramas) dividida pelo comprimento naso-anal (CNA; milímetros) multiplicado por 10000) (Rogers, 1980) e o Índice de adiposidade (gordura corporal total dividida pelo peso corporal final multiplicado por 100) adaptado de Boustany et al. (2004) foram calculados. 


\section{6- Eficiência Alimentar e Ingestão Calórica}

Com a finalidade de analisar a capacidade de o animal converter a energia alimentar consumida em peso corporal, foi calculada a eficiência alimentar (EA), dividindo-se o ganho total de peso dos animais (g) pela energia total ingerida (Kcal) (SURWIT, 1995). A ingestão calórica foi calculada da seguinte forma: ingestão alimentar semanal multiplicada pelo valor calórico de cada dieta ( $\mathrm{g}$ x kcal).

\section{7- Análise Bioquímica}

Os animais foram submetidos a jejum por 12 a 15 horas, anestesiados com pentobarbital sódico, $50 \mathrm{mg} / \mathrm{kg}$ intraperitoneal, e sacrificados por decapitação. O sangue foi coletado em tubos secos, em seguida, centrifugado a 3000 rpm por 10 minutos e o soro armazenado a $-80^{\circ} \mathrm{C}$. As concentrações séricas de glicose, triacilglicerol (TG), colesterol total (Col), lipoproteína de alta densidade (HDL) e lipoproteína de baixa densidade (LDL) foram determinadas por kits específicos $\left(\right.$ CELM $^{\circledR}$, São Paulo, Brasil). As dosagens foram analisadas pelo método enzimático colorimétrico automatizado (Technicon, RA-XT ${ }^{\mathrm{TM}}$ System, Global Medical Instrumentation, Minessota, USA).

\section{8- Dosagens Hormonais}

Foram dosados no soro (coleta descrita anteriormente), de todos os animais, a concentração sérica de insulina, leptina, $\mathrm{T}_{3}$ livre, $\mathrm{T}_{4}$ livre e TSH. Kits comerciais foram utilizados para a dosagem de leptina, insulina (kit ELISA Linco Research), e hormônios tireoidianos (Kit ELISA USCN Life Science \& Technology Company).

\section{9- Ensaio Cometa}

Foi utilizado sangue periférico para detecção de danos oxidativos no DNA. O isolamento dos linfócitos foi feito conforme descrito por Giovanelli et al. (2002). Vários trabalhos indicam a aplicabilidade dos linfócitos para se avaliar os danos oxidativos ao DNA, tendo em vista que estes são excelentes marcadores das condições de saúde do corpo (OLDHAM, 2002). Para determinação dos danos 
oxidativos foi utilizada a versão alcalina do ensaio cometa conforme descrita por Singh et al. (1988), com modificações introduzidas por Collins et al. (1998). Foram analisados, de cada animal, 100 linfócitos (50 células por lâmina), em microscópio de fluorescência acoplado a sistema de análise de imagens (Comet Assay II, Perceptives Instruments, UK). Segue em anexo o protocolo da técnica. Para a análise da eficiência do sistema reparo, amostras de linfócitos dos animais foram expostas a $\mathrm{H}_{2} \mathrm{O}_{2}$ para indução de dano e logo após o desafio com $\mathrm{H}_{2} \mathrm{O}_{2}$, para verificar a eficiência do sistema de reparo (RIBEIRO et al., 2003).

\subsection{0- Análise Estatística}

Os dados foram expressos em média \pm desvio padrão. Para comparar a evolução do peso corporal entre os grupos foi utilizado o intervalo de confiança de 95\%; para as variáveis morfométricas, nutricionais, bioquímicas, avaliação da gordura corporal, área sob a curva glicêmica, dosagens hormonais e ensaio cometa foi utilizada a técnica da análise de variância (ANOVA) de duas vias, completamente casualizado, complementada com o teste de Bonferroni. O nível de significância considerado para todas as variáveis foi de $5 \%$. 


\section{5- Resultados}

\section{1- Constituição dos grupos}

No inicio do experimento foram utilizados 70 animais e separados em $15 \mathrm{C} \mathrm{e}$ 55 OB. É importante salientar que dois animais do grupo OB morreram antes da caracterização dos grupos. Após a aplicação do critério para caracterização dos grupos, o grupo $\mathrm{C}$ foi constituído por 11 animais e o OB por 41. Assim, a perda foi de 4 animais C (26,7\%) e de 12 animais OB (22,6\%). Para que cada grupo experimental fosse composto por 10 animais, um animal do grupo $\mathrm{C}$ e um do $\mathrm{OB}$ foi sorteado aleatoriamente e excluído do estudo. As Figura 3 e 4 apresentam o critério de exclusão e o delineamento do estudo após o critério, respectivamente.

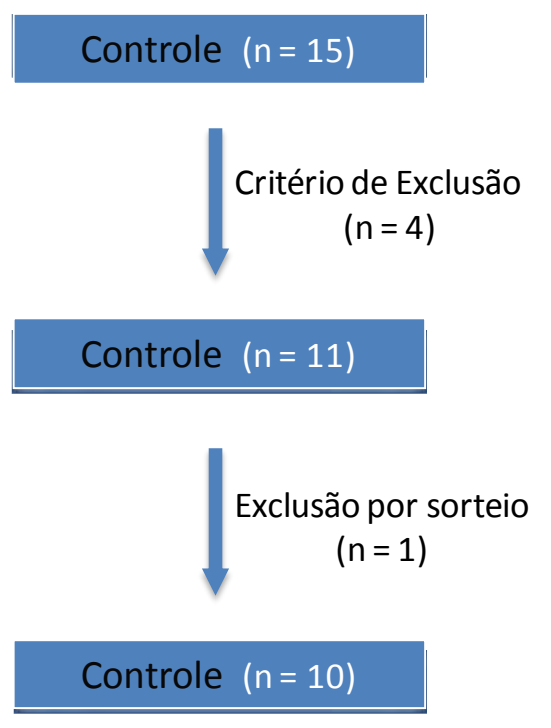

\section{Obeso $(n=55)$}

Morreram

$(n=2)$

\section{Obeso $(n=53)$}

Critério de Exclusão $(n=12)$

\section{Obeso $(n=41)$}

Exclusão por sorteio $(n=1)$

\section{Obeso $(n=40)$}

Figura 3- Critério de exclusão. C, controle; $\mathrm{OB}$, obeso. 


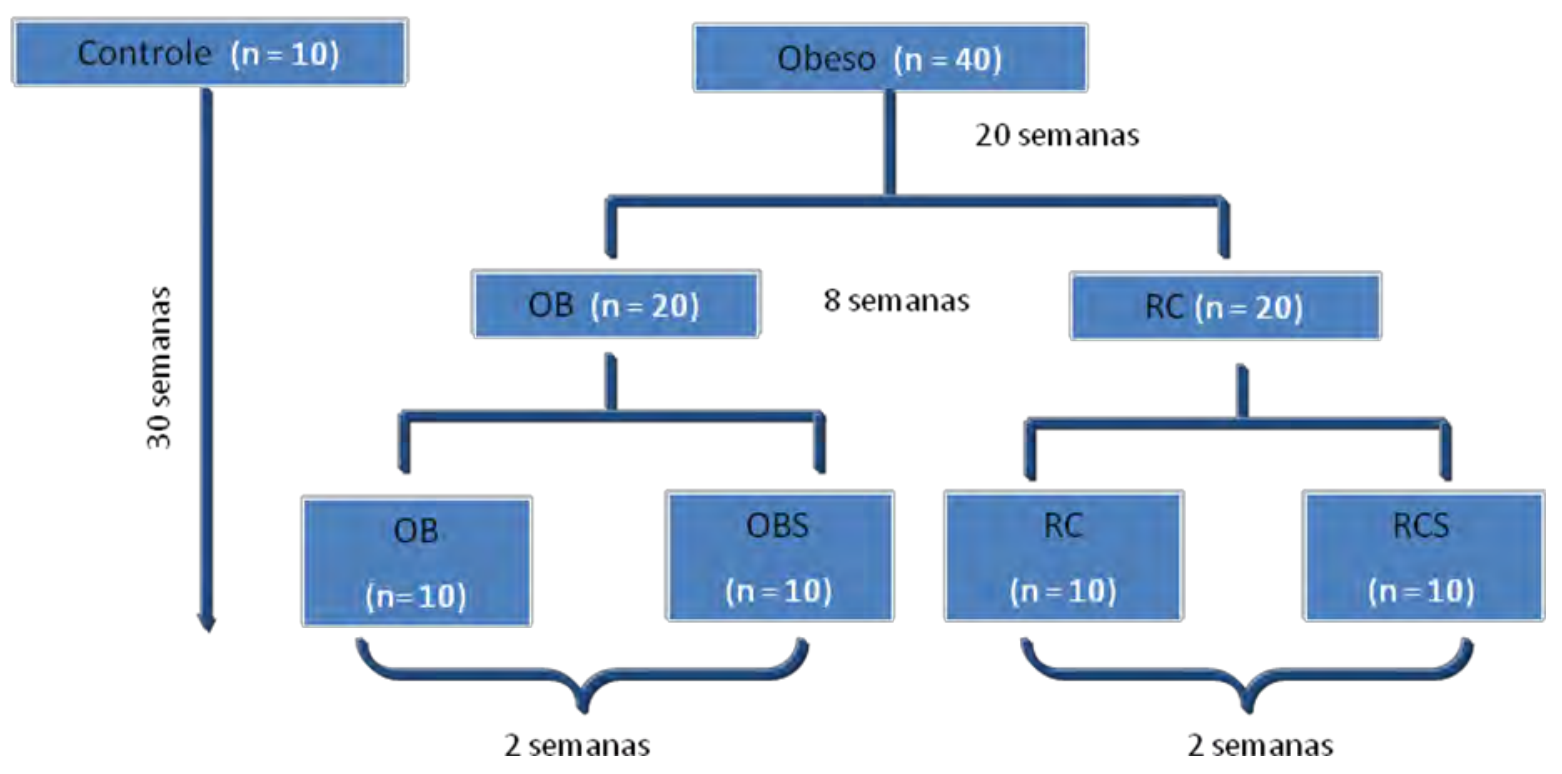

Figura 4- Delineamento do estudo após caracterização dos grupos (critério de exclusão). C, controle; $\mathrm{OB}$, obeso; RC, restrição calórica, OBS, obeso com dose de triiodotironina na concentração de 25 $\mu \mathrm{g} / 100 \mathrm{~g}$ de peso; RCS, restrição com dose de triiodotironina na concentração de $25 \mu \mathrm{g} / 100 \mathrm{~g}$ de peso.

\section{2- Caracterização dos grupos}

\subsection{1- Evolução de Peso}

A evolução do peso dos animais está apresentada na Figura 3. Os animais que consumiram as dietas hipercalóricas apresentaram maior ganho de peso a partir da $12^{\text {a }}$ semana de experimento. Após a $2^{\text {a }}$ semana de instauração da restrição calórica o grupo RC apresentou peso semelhante ao grupo C. Houve estabilização do peso corporal dos animais RC a partir da $5^{\text {a }}$ semana de restrição alimentar, quando a perda de peso atingiu, em média, $11,1 \%$ do peso corporal. O tratamento com $T_{3}$ reduziu o peso em todos os grupos tratados (OBS e RCS) e os animais RCS apresentaram diminuição de peso em comparação ao grupo $\mathrm{C}$. 


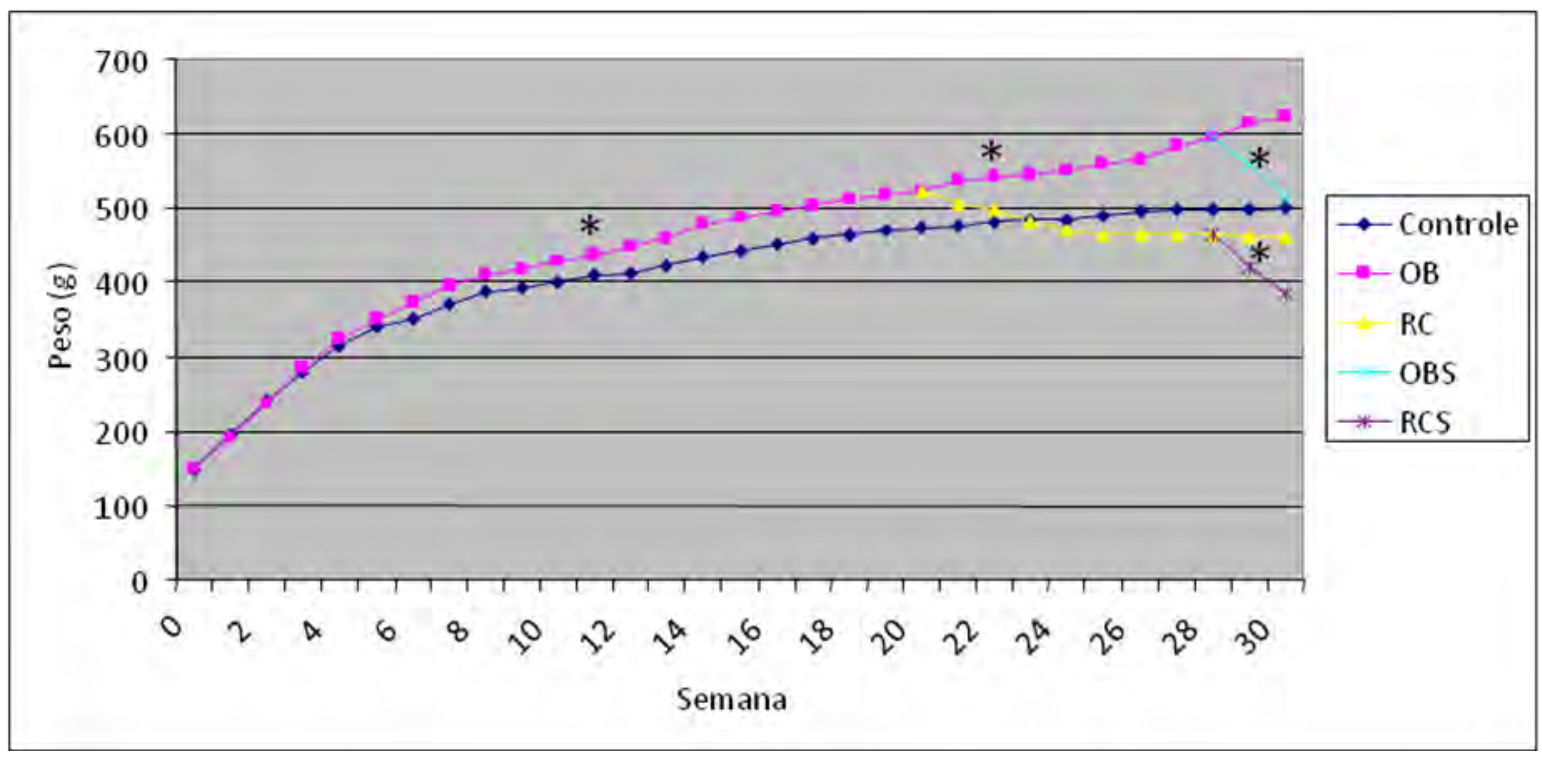

Figura 5- Evolução semanal do peso corporal dos grupos controle $(n=10)$, obeso $(O B, n=50)$, obeso com $25 \mu \mathrm{g} / 100 \mathrm{~g}$ de T3 (OBS, $\mathrm{n}=10$ ), restrição calórica ( $\mathrm{RC}, \mathrm{n}=10$ ) e restrito com $25 \mu \mathrm{g} / 100 \mathrm{~g}$ de T3 (RCS, $n=10)$. Dados expressos em média.

Todos os animais apresentavam pesos semelhantes no início do estudo. Após o período de indução de obesidade, os animais que consumiram dieta hipercalórica apresentaram peso corporal maior que os animais com dieta controle. Houve perda de peso nos animais submetidos à restrição alimentar e a administração de dose supra fisiológica de $T_{3}$ provocou maior perda de peso. Não houve diferença estatística para comprimento naso-anal em todos os grupos estudados (Tabela 2). 
Tabela 2. Características morfométricas: peso corporal inicial e final, e comprimento naso-anal

\begin{tabular}{|c|c|c|c|}
\hline \multirow[b]{2}{*}{ Variável } & \multirow[b]{2}{*}{ Grupos } & \multicolumn{2}{|c|}{ Tratamento } \\
\hline & & Salina & $25 \mu \mathrm{g} \mathrm{T}_{3} / 100 \mathrm{~g}$ \\
\hline & C & $150,12 \pm 5,07 \mathrm{a}$ & ---- \\
\hline \multirow[t]{3}{*}{$\mathrm{PCl}(\mathrm{g})$} & $\mathrm{OB}$ & $146,84 \pm 8,50 \mathrm{Aa}$ & $147,7 \pm 5,80 \mathrm{Aa}$ \\
\hline & $\mathrm{RC}$ & $150,7 \pm 5,89 \mathrm{Aa}$ & $150,4 \pm 7,99 \mathrm{Aa}$ \\
\hline & $\mathrm{C}$ & $487,56 \pm 24,42 \mathrm{a}$ & (n-.-- \\
\hline \multirow[t]{3}{*}{ PCF (g) } & OB & $621,66 \pm 74,05 \mathrm{Bb}$ & $489,50 \pm 48,47 \mathrm{Ab}$ \\
\hline & $\mathrm{RC}$ & $463,10 \pm 28,90 \mathrm{Ba}$ & $370,94 \pm 35,19 \mathrm{Aa}$ \\
\hline & $\mathrm{C}$ & $27,2 \pm 0,98 a$ & $\cdots-$ \\
\hline \multirow[t]{2}{*}{ CNA $(\mathrm{cm})$} & $\mathrm{OB}$ & $28,1 \pm 0,80 \mathrm{Aa}$ & $27,9 \pm 0,77 \mathrm{Aa}$ \\
\hline & $\mathrm{RC}$ & $27,9 \pm 0,77 \mathrm{Aa}$ & $27,1 \pm 1,54 \mathrm{Aa}$ \\
\hline
\end{tabular}

T3, triiodotironina; $\mathrm{PCl}$, peso corporal inicial; PCF, peso corporal final; CNA, comprimento naso-anal; C, controle; $\mathrm{OB}$, obeso; RC, restrição calórica. Dados expressos em média \pm desvio-padrão. Letras maiúsculas, comparações dentro do grupo ( $\mathrm{OB} \times \mathrm{OBS}$ ou $\mathrm{RC} \times \mathrm{RCS})$; letras minúsculas, comparações entre os grupos ( $C \times \mathrm{OB} \times \mathrm{RC}$ ou OBS $\times \mathrm{RCS}$ ); letras iguais $=p>0,05$; letras diferentes $=p<0,05$.

Apesar do grupo OB ingerir menos dieta, seu consumo calórico foi maior que no grupo C. O grupo RC apresenta diminuição na quantidade de ração e calorias ingeridas quando comparado aos grupos $\mathrm{C}$ e OB. O mesmo ocorre ao grupo RCS em relação aos OBS. A eficiência alimentar no grupo OB foi maior em relação aos demais grupos, enquanto doses suprafisiológicas de T3 diminuem a eficiência alimentar (Tabela 3). 
Tabela 3. Características nutricionais: ingestão de ração (g), ingestão calórica (kcal) e eficiência alimentar (EA)

\begin{tabular}{|c|c|c|c|}
\hline \multirow[b]{2}{*}{ Variável } & \multirow[b]{2}{*}{ Grupos } & \multicolumn{2}{|c|}{ Tratamento } \\
\hline & & Salina & $25 \mu \mathrm{g} \mathrm{T}_{3} / 100 \mathrm{~g}$ \\
\hline & C & $25,68 \pm 1,01 \mathrm{c}$ & ----- \\
\hline Ingestão & OB & $22,24 \pm 2,47 \mathrm{Ab}$ & $21,43 \pm 1,23 \mathrm{Aa}$ \\
\hline \multirow[t]{2}{*}{ (g) } & $\mathrm{RC}$ & $20,34 \pm 057 \mathrm{Aa}$ & $19,74 \pm 0,79 \mathrm{Aa}$ \\
\hline & $\mathrm{C}$ & $73,66 \pm 2,89 b$ & ( \\
\hline Ingestão & $\mathrm{OB}$ & $84,14 \pm 9,33 \mathrm{Ac}$ & $81,09 \pm 4,67 \mathrm{Ab}$ \\
\hline \multirow[t]{2}{*}{ (kcal) } & $\mathrm{RC}$ & $68,09 \pm 2,15 \mathrm{Aa}$ & $65,81 \pm 2,99 \mathrm{Aa}$ \\
\hline & $\mathrm{C}$ & $4,57 \pm 0,27 a$ & ( \\
\hline EA & OB & $5,64 \pm 0,51 \mathrm{Bb}$ & $4,56 \pm 0,40 \mathrm{Ab}$ \\
\hline$(\mathrm{kcal} / \mathrm{g})$ & $\mathrm{RC}$ & $4,58 \pm 0,39 \mathrm{Ba}$ & $3,35 \pm 0,50 \mathrm{Aa}$ \\
\hline
\end{tabular}

T3, triiodotironina; EA, eficiência alimentar; C, controle; OB, obeso; RC, restrição calórica. Dados expressos em média \pm desvio-padrão. Letras maiúsculas, comparações dentro do grupo (OB $\times$ OBS ou RC x RCS); letras minúsculas, comparações entre os grupos ( $\mathrm{C} \times \mathrm{OB} \times \mathrm{RC}$ ou OBS $\times \mathrm{RCS}$ ); letras iguais $=p>0,05$; letras diferentes $=p<0,05$.

As figuras 6, 7 e 8 mostram a gordura corporal total e o índice de adiposidade e Índice de Lee, respectivamente. Todas as variáveis apresentaram o mesmo comportamento, sendo que o grupo $\mathrm{OB}$ mostrou aumento significativo quando comparado aos grupos $\mathrm{C}, \mathrm{RC}$ e OBS. $\mathrm{O}$ grupo $\mathrm{RC}$ foi similar ao grupo $\mathrm{C}$, enquanto RCS mostrou diminuição significativa para estas variáveis. 


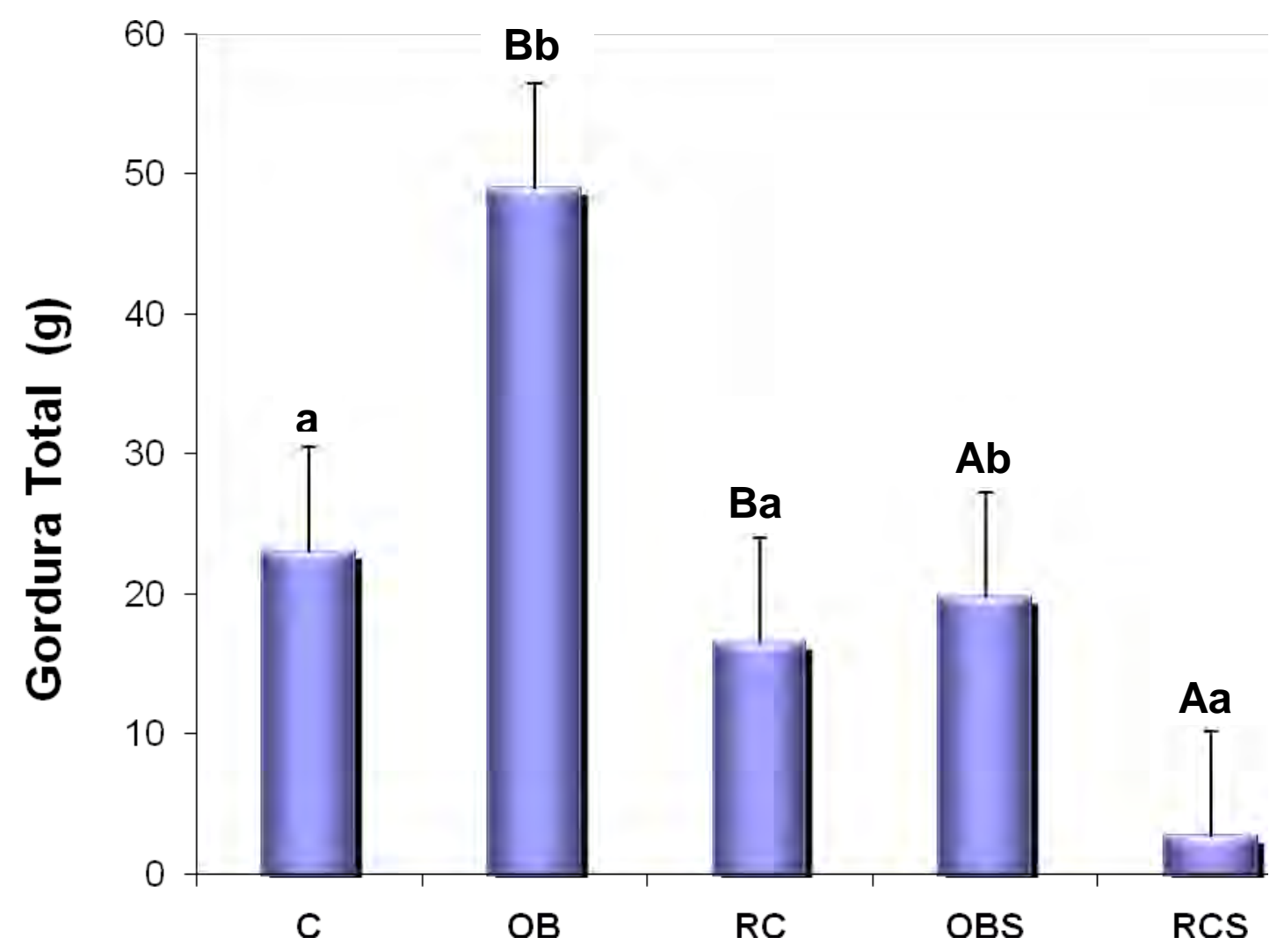

Figura 6- Quantificação da gordura total. C, controle; OB, obeso; RC, restrição calórica; OBS, obeso com dose de $25 \mu \mathrm{g}$ de Triiodotironina/100g; RCS, restrito com dose de $25 \mu \mathrm{g}$ de Triiodotironina/100g. Dados expressos em média \pm desvio-padrão. Letras maiúsculas, comparações dentro do grupo (OB $\mathrm{x}$ OBS ou RC $\times R C S$ ); letras minúsculas, comparações entre os grupos ( $C \times O B \times R C$ ou OBS $\times R C S$ ); letras iguais $=p>0,05$; letras diferentes $=p<0,05$. 


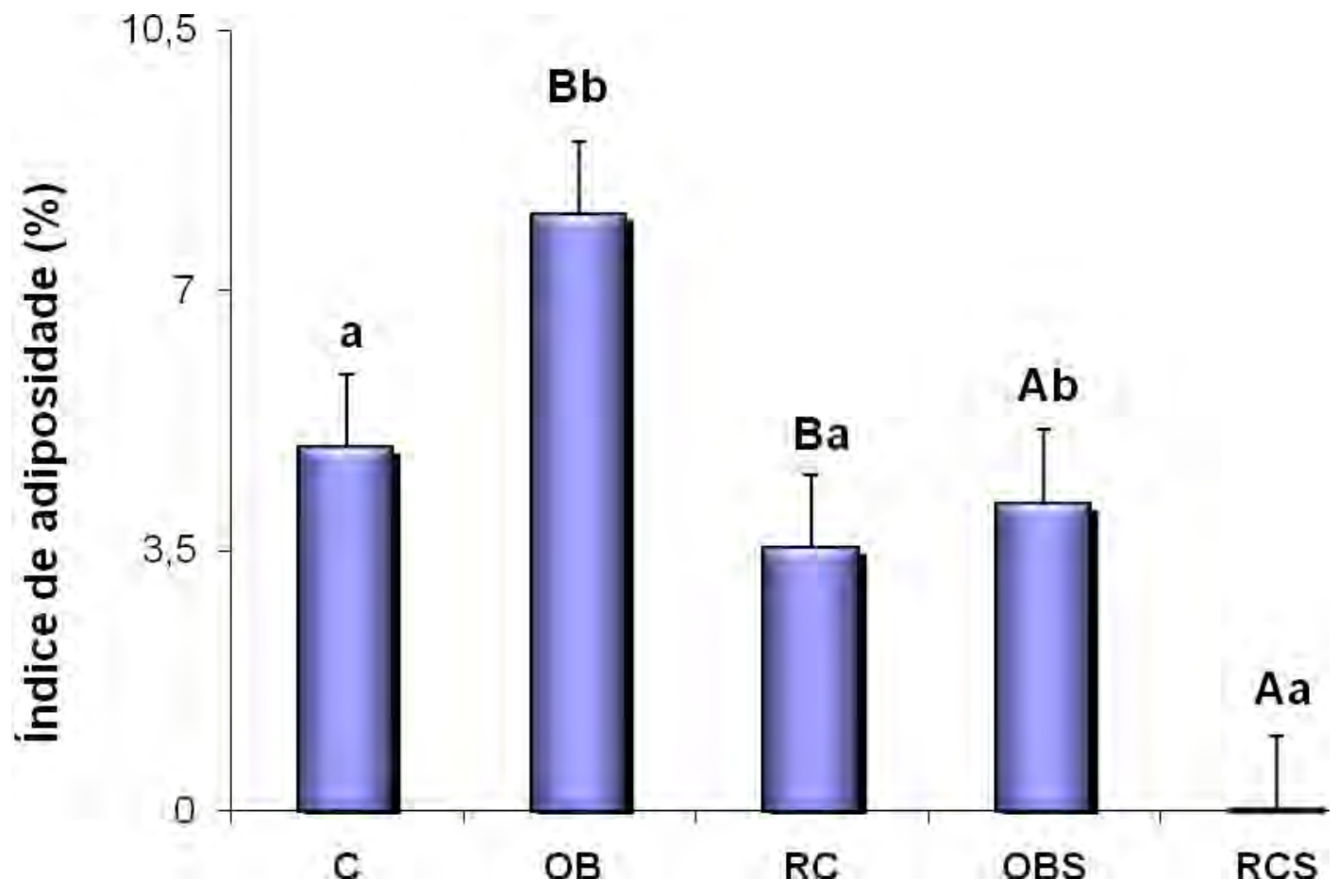

Figura 7- Índice de Adiposidade. C, controle; OB, obeso; RC, restrição calórica; OBS, obeso com dose de $25 \mu \mathrm{g}$ de Triiodotironina/100g; RCS, restrito com dose de $25 \mu \mathrm{g}$ de Triiodotironina/100g. Dados expressos em média \pm desvio-padrão. Letras maiúsculas, comparações dentro do grupo (OB $\times$ OBS ou RC $\times$ RCS); letras minúsculas, comparações entre os grupos ( $\mathrm{C} \times \mathrm{OB} \times \mathrm{RC}$ ou OBS $\times \mathrm{RCS}$ ); letras iguais $=p>0,05$; letras diferentes $=p<0,05$. 


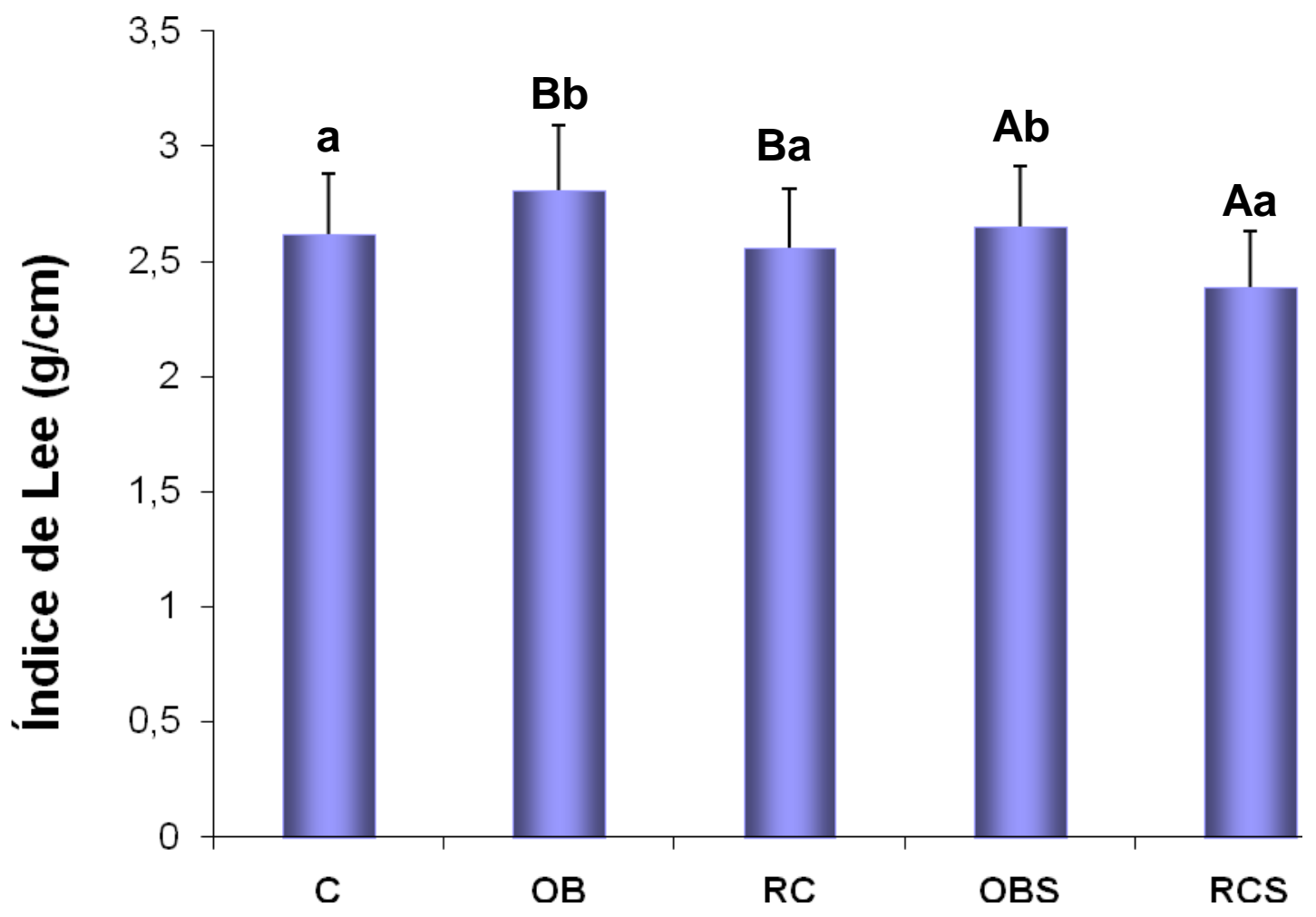

Figura 8- Índice de Lee. C, controle; OB, obeso; RC, restrição calórica; OBS, obeso com dose de $25 \mu \mathrm{g}$ de Triiodotironina/100g; RCS, restrito com dose de $25 \mu \mathrm{g}$ de Triiodotironina/100g. Dados expressos em média \pm desvio-padrão. Letras maiúsculas, comparações dentro do grupo (OB $\times$ OBS ou RC x RCS); letras minúsculas, comparações entre os grupos ( $\mathrm{C} \times \mathrm{OB} \times \mathrm{RC}$ ou OBS $\times \mathrm{RCS}$ ); letras iguais $=p>0,05$; letras diferentes $=p<0,05$.

\section{3- Análise Bioquímica}

A Tabela 4 apresenta valores para glicose, colesterol total (Col), triacilglicerol (TG), lipoproteína de alta densidade (HDL) e lipoproteína de baixa densidade (LDL). Nos níveis de glicose, não houve diferença estatística entre os animais que receberam salina; contudo, os animais OBS mostraram aumento significativo em relação ao grupo RCS. Para colesterol total, apenas o grupo RC apresentou níveis diminuídos quando comparado ao grupo $\mathrm{OB}$. Os níveis de TG foram diminuídos nos animais $\mathrm{C}$ e $\mathrm{RC}$ em relação ao grupo $\mathrm{OB}$. HDL foi estatisticamente elevado no grupo $\mathrm{OB}$ quando comparado ao $\mathrm{C}$ e RC e LDL foi significativamente diminuído nos grupos OBS e RCS quando comparado aos grupos OB e RC, respectivamente. 
Tabela 4. Análise bioquímica: glicose, colesterol total, triglicérides, HDL, LDL e ácidos graxos livres

\begin{tabular}{|c|c|c|c|}
\hline \multirow[b]{2}{*}{ Variável } & \multirow[b]{2}{*}{ Grupos } & \multicolumn{2}{|c|}{ Tratamento } \\
\hline & & Salina & $25 \mu \mathrm{g} \mathrm{T}_{3} / 100 \mathrm{~g}$ \\
\hline & $\mathrm{C}$ & $89,00 \pm 6,24$ a & ----- \\
\hline Glicose & $\mathrm{OB}$ & $92,50 \pm 8,37 \mathrm{Aa}$ & $103,9 \pm 11,22 \mathrm{Bb}$ \\
\hline \multirow[t]{2}{*}{$(\mathrm{mg} / \mathrm{dL})$} & $\mathrm{RC}$ & $85,50 \pm 5,74 \mathrm{Aa}$ & $79,60 \pm 14,8 \mathrm{Aa}$ \\
\hline & $\mathrm{C}$ & $92,30 \pm 5,95 \mathrm{ab}$ & ） \\
\hline Col. Total & OB & $93,40 \pm 14,32 \mathrm{Ab}$ & $77,70 \pm 18,52 \mathrm{Aa}$ \\
\hline \multirow[t]{2}{*}{$(\mathrm{mg} / \mathrm{dL})$} & $\mathrm{RC}$ & $74 \pm 11,91 \mathrm{Aa}$ & $69,50 \pm 10,83 \mathrm{Aa}$ \\
\hline & $\mathrm{C}$ & $79,80 \pm 39,09 a$ & ） \\
\hline TG & OB & $86 \pm 10,48 \mathrm{Ab}$ & $75,70 \pm 23,20 \mathrm{Ab}$ \\
\hline \multirow[t]{2}{*}{$(\mathrm{mg} / \mathrm{dL})$} & $\mathrm{RC}$ & $70,40 \pm 4,73 \mathrm{Aa}$ & $45,60 \pm 17,93 \mathrm{Aa}$ \\
\hline & $\mathrm{C}$ & $67,60 \pm 16,47 a$ & - \\
\hline HDL & $\mathrm{OB}$ & $83,11 \pm 19,54 \mathrm{Ab}$ & $73,92 \pm 10,76 \mathrm{Aa}$ \\
\hline \multirow[t]{2}{*}{$(\mathrm{mg} / \mathrm{dL})$} & $\mathrm{RC}$ & $63,80 \pm 0,76 \mathrm{Aa}$ & $71,30 \pm 10,88 \mathrm{Aa}$ \\
\hline & $\mathrm{C}$ & $19,10 \pm 4,98 \mathrm{a}$ & (---- \\
\hline LDL & $\mathrm{OB}$ & $17,40 \pm 5,19 \mathrm{Ba}$ & $8,26 \pm 2,70 \mathrm{Aa}$ \\
\hline (mg/dL) & $\mathrm{RC}$ & $15,80 \pm 2,74 \mathrm{Ba}$ & $8,90 \pm 2,60 \mathrm{Aa}$ \\
\hline
\end{tabular}

T3, triiodotironina; Col. Total, colesterol total; TG, triglicérides; HDL, lipoproteína de alta densidade; LDL, lipoproteína de baixa densidade; $C$, controle; $O B$, obeso; RC, restrição calórica. Dados expressos em média \pm desvio-padrão. Letras maiúsculas, comparações dentro do grupo (OB $\times$ OBS ou RC $\times$ RCS); letras minúsculas, comparações entre os grupos ( $\mathrm{C} \times \mathrm{OB} \times \mathrm{RC}$ ou OBS $\times \mathrm{RCS}$ ); letras iguais $=p>0,05$; letras diferentes $=p<0,05$.

\section{4- Teste de Tolerância à Insulina}

Ao final do experimento, os animais foram submetidos ao teste de tolerância à insulina. Para evidenciar resistência à insulina, a área sob a curva glicêmica foi analisada e a razão insulina/glicose plasmática foi calculada (Tabela 5). A área sob a curva glicêmica mostrou aumento estatístico no grupo OBS em relação à RCS. A razão insulina/glicose foi aumentada nos animais $\mathrm{OB}$ em relação aos grupos $\mathrm{C}, \mathrm{RC}$ e OBS. 
Tabela 5. Área sob a curva glicêmica e razão insulina/glicose plasmática

\begin{tabular}{|c|c|c|c|}
\hline \multirow[b]{2}{*}{ Variável } & \multirow[b]{2}{*}{ Grupos } & \multicolumn{2}{|c|}{ Tratamento } \\
\hline & & Salina & $25 \mu \mathrm{g} \mathrm{T}_{3} / 100 \mathrm{~g}$ \\
\hline & C & $2004 \pm 305 a b$ & ----- \\
\hline$A C G$ & OB & $2229 \pm 188 \mathrm{Ab}$ & $2339 \pm 381 \mathrm{Ab}$ \\
\hline \multirow[t]{2}{*}{$(\mathrm{mm} 2)$} & $\mathrm{RC}$ & $1749 \pm 255 \mathrm{Aa}$ & $1646 \pm 226 \mathrm{Aa}$ \\
\hline & $\mathrm{C}$ & $12,52 \pm 7,00 \mathrm{a}$ & $-\cdots$ \\
\hline \multirow[t]{2}{*}{ Ins/Gli } & OB & $20,08 \pm 6,55 \mathrm{Bb}$ & $11,13 \pm 3,51 \mathrm{Aa}$ \\
\hline & $\mathrm{RC}$ & $13,25 \pm 3,80 \mathrm{Ba}$ & $6,80 \pm 3,00 \mathrm{Aa}$ \\
\hline
\end{tabular}

T3, triiodotironina; ACG: área sob a curva glicêmica; Ins/Gli: razão insulina/glicose plasmática; C, controle; $\mathrm{OB}$, obeso; RC, restrição calórica. Dados expressos em média \pm desvio-padrão. Letras maiúsculas, comparações dentro do grupo ( $\mathrm{OB} \times \mathrm{OBS}$ ou $\mathrm{RC} \times \mathrm{RCS})$; letras minúsculas, comparações entre os grupos ( $C \times \mathrm{OB} \times \mathrm{RC}$ ou OBS $\times \mathrm{RCS}$ ); letras iguais $=p>0,05$; letras diferentes $=p<0,05$.

\section{5- Dosagens Hormonais}

As concentrações séricas para insulina mostraram aumento significante no grupo OB. O grupo OBS apresentou níveis elevados em relação ao grupo RCS (Figura 9). Houve aumento nos níveis de leptina nos animais que receberam as dietas hipercalóricas. Os grupos OBS e RCS apresentaram diminuição nos níveis de leptina quando comparados com os animais OB e RC (Figura 10).

Os níveis de T3 livre foram diminuídos no grupo $\mathrm{RC}$ quando comparado ao $\mathrm{C}$, mas não ao OB. A dose administrada aumentou os níveis de hormônio nos animais RCS e OBS (Figura 11). Já os níveis de T4 livre diminuíram nos animais RC em relação aos $\mathrm{OB}$, que foram estatisticamente menores que os do $\mathrm{C}$. Houve diminuição para OBS quando comparado OB. (Figura 12). Os níveis de TSH acompanharam os de T4, exceto para o grupo OB que foi semelhante ao $\mathrm{C}$ (Figura 13). 


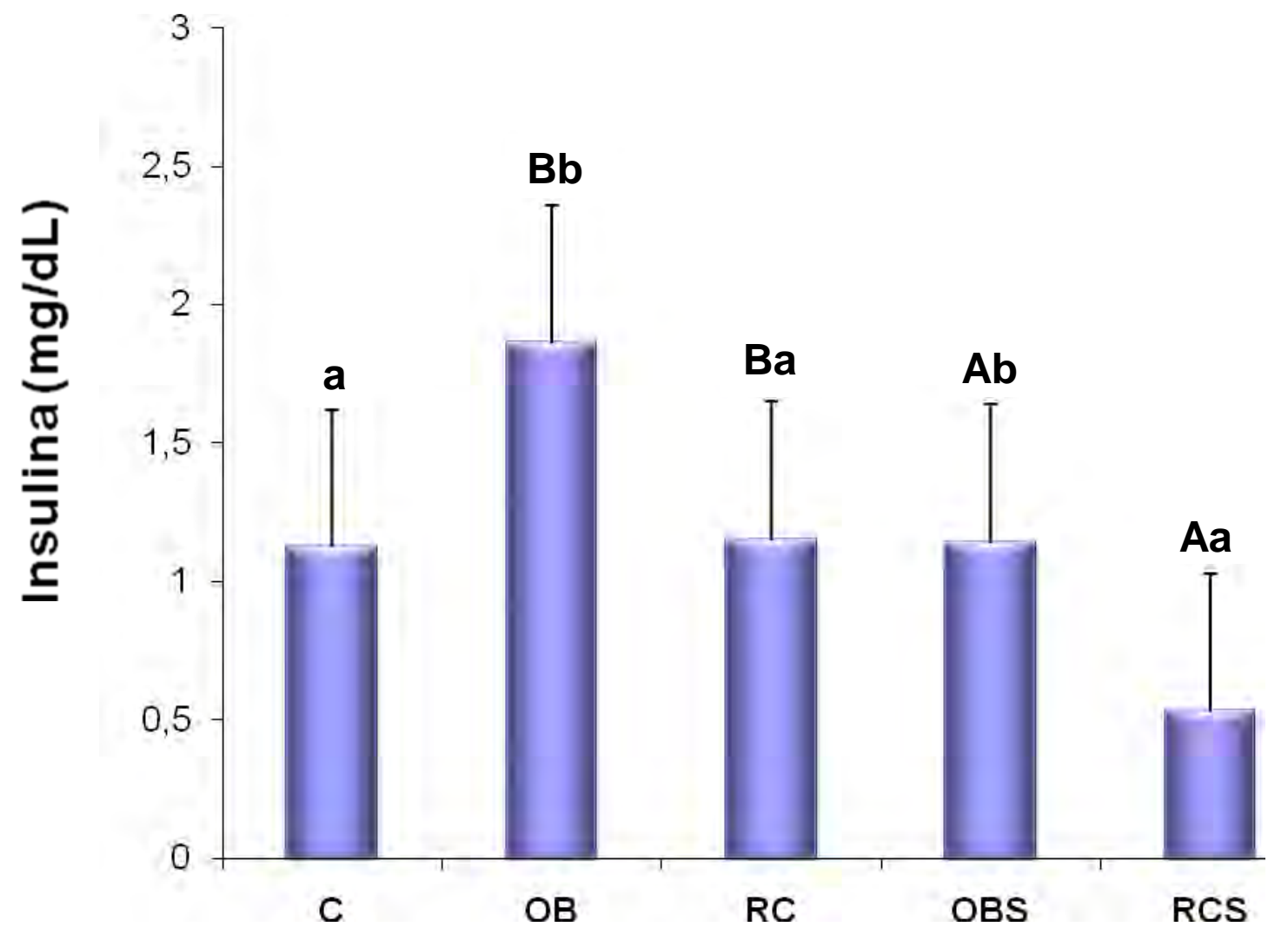

Figura 9- Concentração sérica de insulina. C, controle; OB, obeso; RC, restrição calórica; OBS, obeso com dose de $25 \mu \mathrm{g}$ de Triiodotironina/100g; RCS, restrito com dose de $25 \mu \mathrm{g}$ de Triiodotironina/100g. Dados expressos em média \pm desvio-padrão. Letras maiúsculas, comparações dentro do grupo (OB $\times$ OBS ou RC $\times$ RCS); letras minúsculas, comparações entre os grupos ( $\mathrm{C} \times \mathrm{OB}$ $x R C$ ou OBS $x$ RCS); letras iguais $=p>0,05$; letras diferentes $=p<0,05$. 


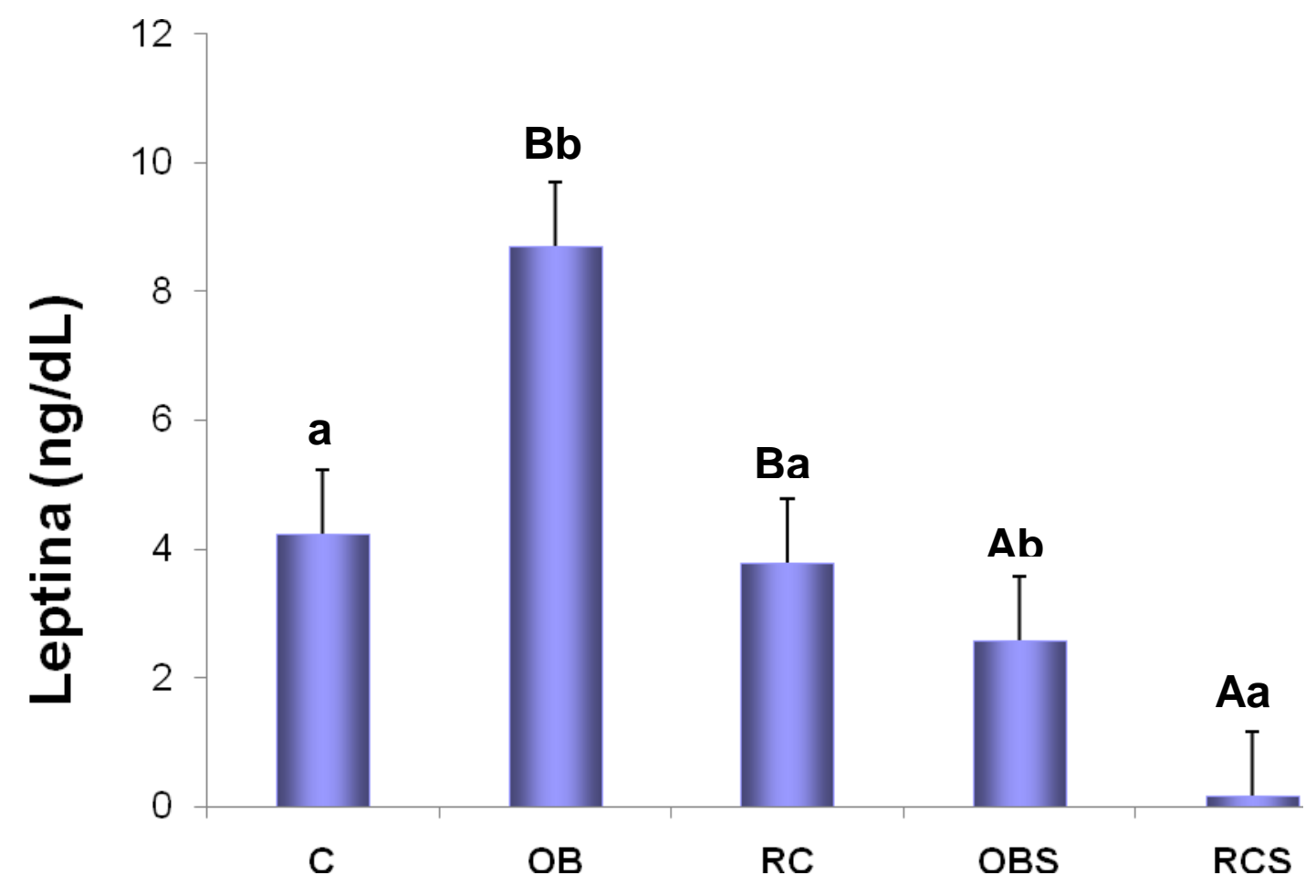

Figura 10- Concentração sérica de leptina. $\mathrm{C}$, controle; $\mathrm{OB}$, obeso; $\mathrm{RC}$, restrição calórica; $\mathrm{OBS}$, obeso com dose de $25 \mu \mathrm{g}$ de Triiodotironina/100g; RCS, restrito com dose de $25 \mu \mathrm{g}$ de Triiodotironina/100g. Dados expressos em média \pm desvio-padrão. Letras maiúsculas, comparações dentro do grupo (OB $\times$ OBS ou $R C \times R C S$ ); letras minúsculas, comparações entre os grupos $(C \times O B$ $x$ RC ou OBS $x$ RCS); letras iguais $=p>0,05$; letras diferentes $=p<0,05$. 


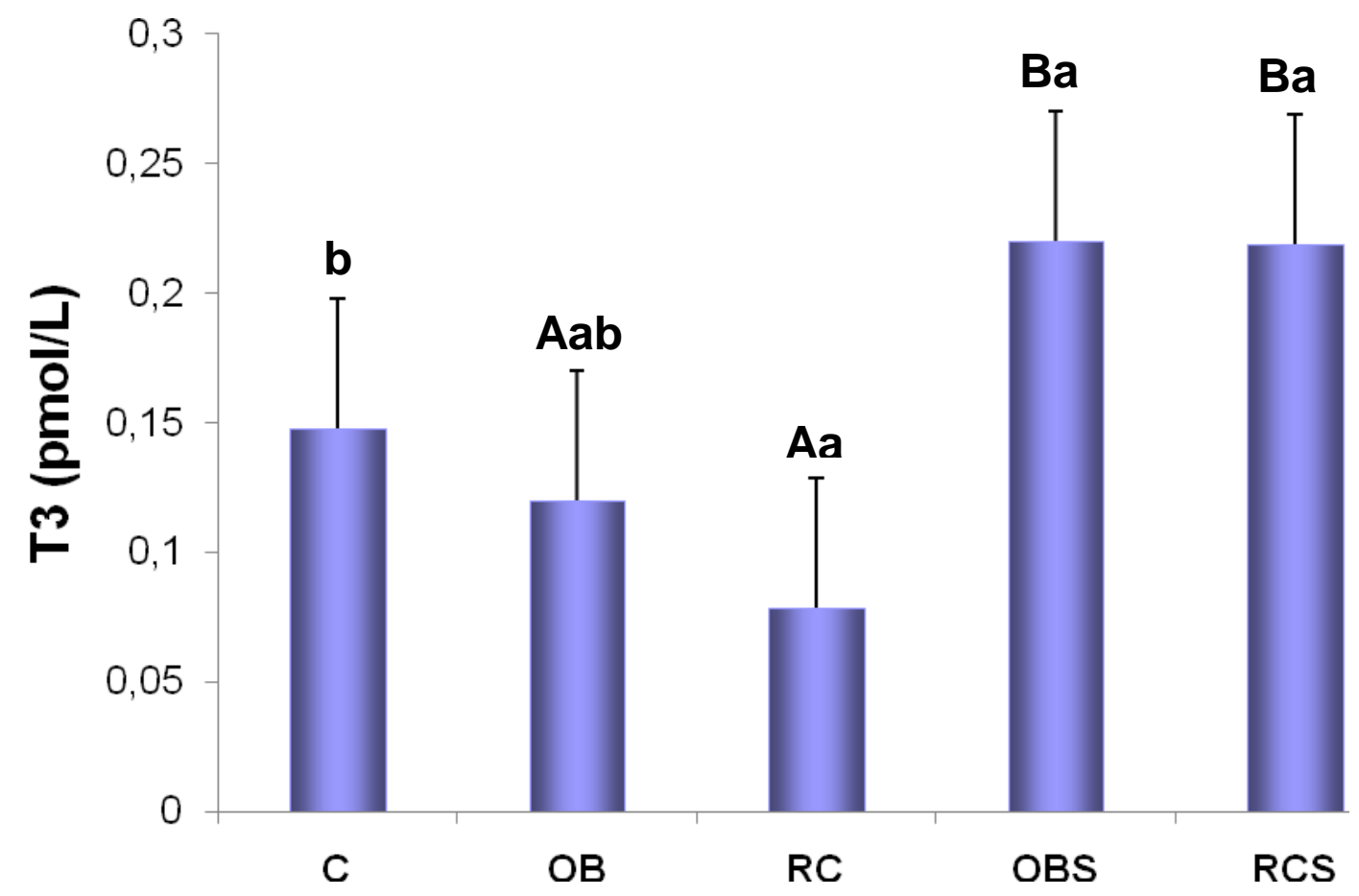

Figura 11- Concentração sérica de triiodotironina (T3 livre). C, controle; $\mathrm{OB}$, obeso; $\mathrm{RC}$, restrição calórica; OBS, obeso com dose de $25 \mu \mathrm{g}$ de Triiodotironina/100g; RCS, restrito com dose de $25 \mu \mathrm{g}$ de Triiodotironina/100g. Dados expressos em média \pm desvio-padrão. Letras maiúsculas, comparações dentro do grupo (OB $\times$ OBS ou RC $\times$ RCS); letras minúsculas, comparações entre os grupos ( $\mathrm{X}$ OB $x R C$ ou OBS $x$ RCS); letras iguais $=p>0,05$; letras diferentes $=p<0,05$. 


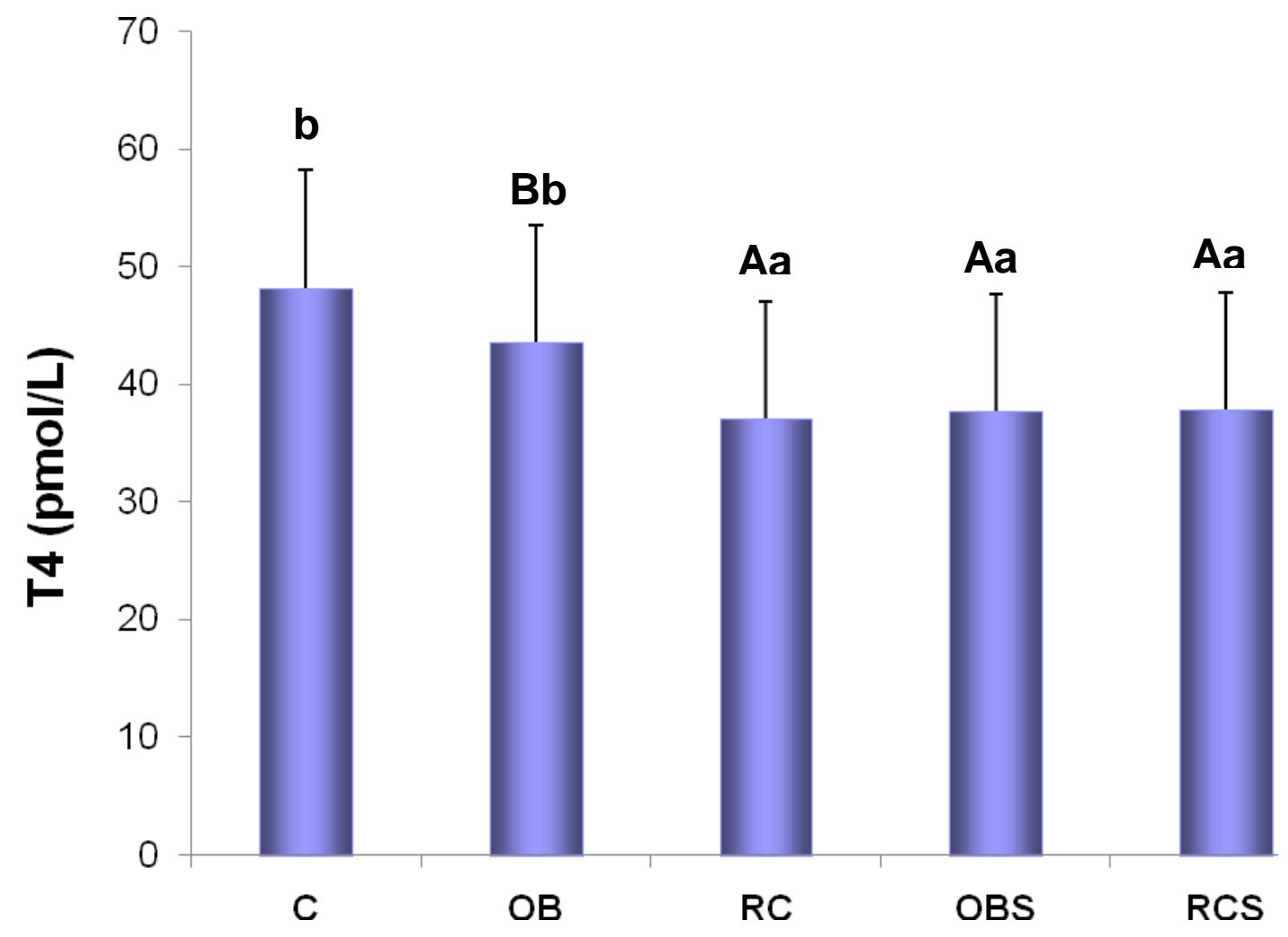

Figura 12- Concentração sérica de tiroxina ( $T 4$ livre). $C$, controle; $O B$, obeso; $R C$, restrição calórica; OBS, obeso com dose de $25 \mu \mathrm{g}$ de Triiodotironina/100g; RCS, restrito com dose de $25 \mu \mathrm{g}$ de Triiodotironina/100g. Dados expressos em média \pm desvio-padrão. Letras maiúsculas, comparações dentro do grupo (OB $\times$ OBS ou $\mathrm{RC} \times \mathrm{RCS}$ ); letras minúsculas, comparações entre os grupos ( $\mathrm{x} \times \mathrm{OB}$ $x$ RC ou OBS $x$ RCS); letras iguais $=p>0,05$; letras diferentes $=p<0,05$. 


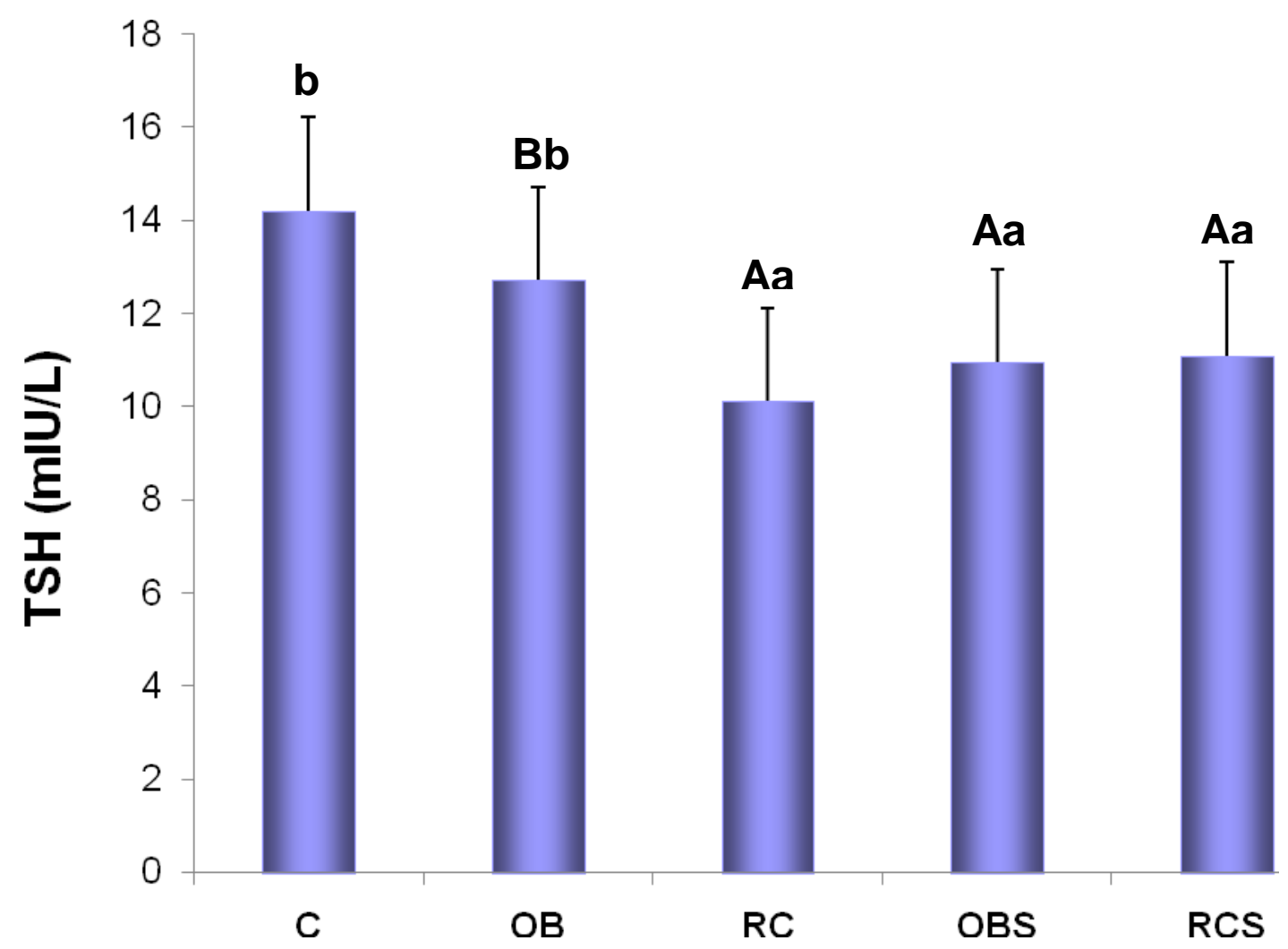

Figura 13- Concentração sérica de hormônio estimulador da tireóide (TSH). C, controle; OB, obeso; $\mathrm{RC}$, restrição calórica; OBS, obeso com dose de $25 \mu \mathrm{g}$ de Triiodotironina/100g; RCS, restrito com dose de $25 \mu \mathrm{g}$ de Triiodotironina/100g. Dados expressos em média \pm desvio-padrão. Letras maiúsculas, comparações dentro do grupo (OB $\times$ OBS ou $R C \times R C S)$; letras minúsculas, comparações entre os grupos ( $C \times O B \times R C$ ou OBS $\times R C S$ ); letras iguais $=p>0,05$; letras diferentes $=p<0,05$.

\section{6-Ensaio Cometa}

A figura 14, mostra a análise dos linfócitos pela técnica do ensaio cometa para avaliar o Dano de DNA.

O grupo OB mostrou aumento significativo nos níveis de dano quando comparado aos grupos $\mathrm{C}$ e RC, porém menores em relação ao grupo OBS. Os animais do grupo RCS apresentaram níveis maiores que os RC e diminuídos em relação aos OBS. 


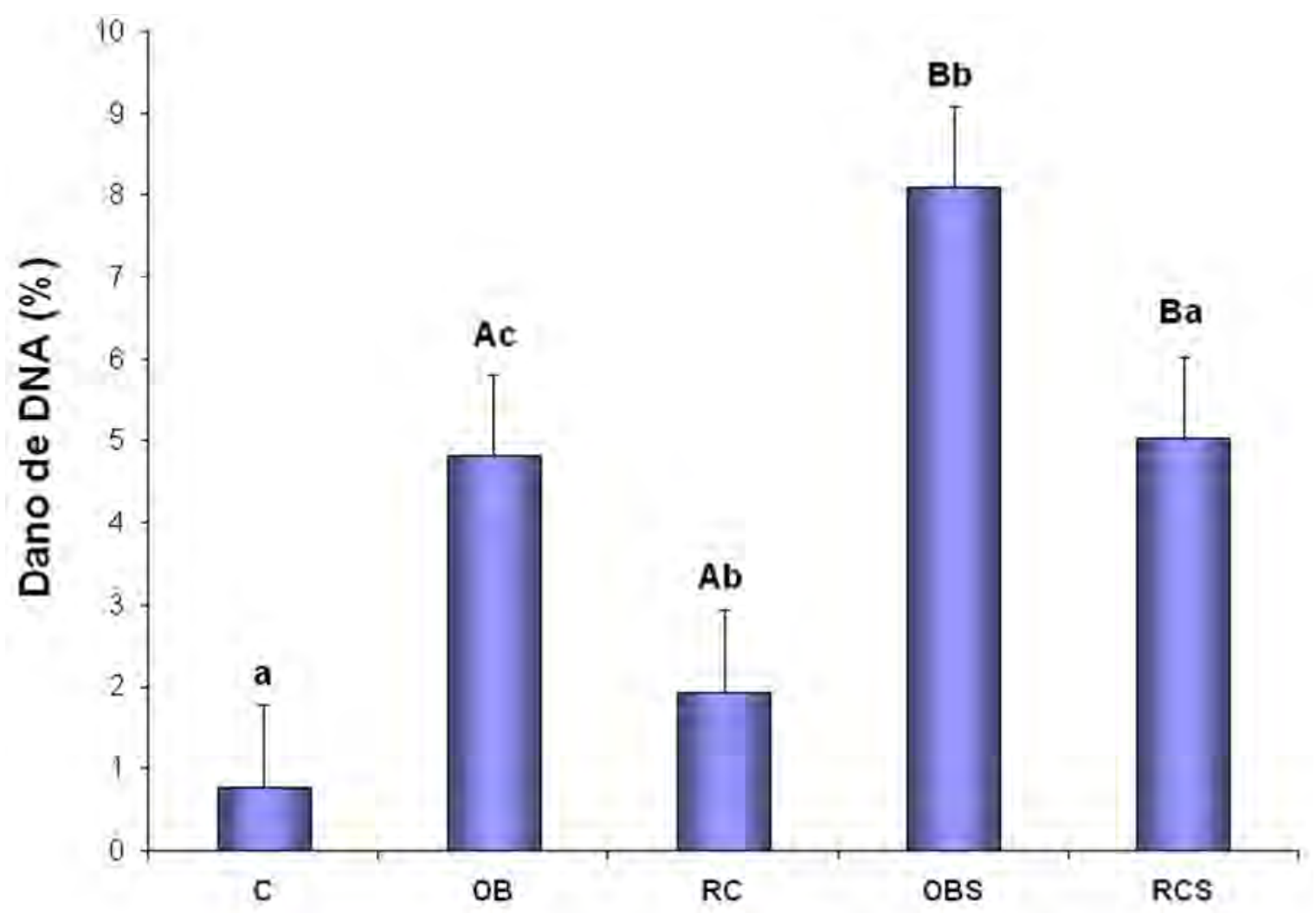

Figura 14- Porcentagem de dano de DNA. C, controle; $\mathrm{OB}$, obeso; RC, restrição calórica; $\mathrm{OBS}$, obeso com dose de $25 \mu \mathrm{g}$ de Triiodotironina/100g; RCS, restrito com dose de $25 \mu \mathrm{g}$ de Triiodotironina/100g. Dados expressos em média \pm desvio-padrão. Letras maiúsculas, comparações dentro do grupo (OB $\times$ OBS ou RC $\times$ RCS); letras minúsculas, comparações entre os grupos ( $\mathrm{X} \times \mathrm{OB}$ $x R C$ ou OBS $x$ RCS); letras iguais $=p>0,05$; letras diferentes $=p<0,05$.

Os animais OBS e RCS mostraram aumento significativo de dano quando expostos a $\mathrm{H}_{2} \mathrm{O}_{2}$ em relação aos grupos $\mathrm{OB}$ e $\mathrm{RC}$, respectivamente. A restrição alimentar, mesmo nos grupo tratado com $\mathrm{T}_{3}$, apresenta níveis menores de dano quando comparados aos OB, contudo são maiores que o C (Figura 15). Entretanto não há diferença significante entre $C$ e $R C$ em relação à porcentagem de reparo, que apresentam eficiência de reparo maior que os animais $O B$. A administração de T3 diminui significativamente a eficiência do sistema de reparo tanto nos grupo RC quanto no OB (Figura 16). 


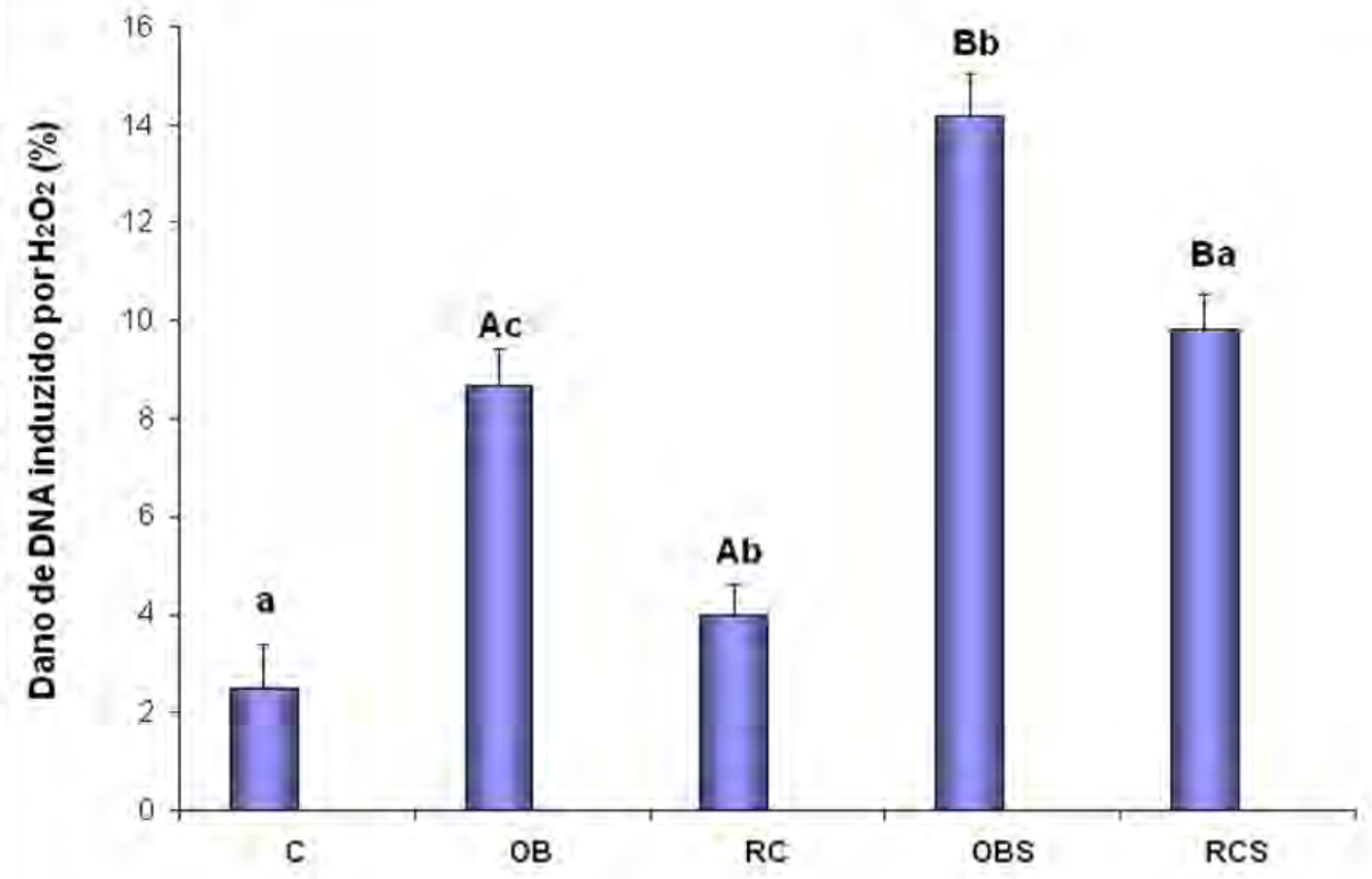

Figura 15- Dano de DNA induzido por $\mathrm{H}_{2} \mathrm{O}_{2}$. C, controle; $\mathrm{OB}$, obeso; $\mathrm{RC}$, restrição calórica; $\mathrm{OBS}$, obeso com dose de $25 \mu \mathrm{g}$ de Triiodotironina/100g; RCS, restrito com dose de $25 \mu \mathrm{g}$ de Triiodotironina/100g. Dados expressos em média \pm desvio-padrão. Letras maiúsculas, comparações dentro do grupo (OB $\times$ OBS ou RC $\times$ RCS); letras minúsculas, comparações entre os grupos ( $\mathrm{C} \times \mathrm{OB}$ $x R C$ ou OBS $x$ RCS); letras iguais $=p>0,05$; letras diferentes $=p<0,05$. 


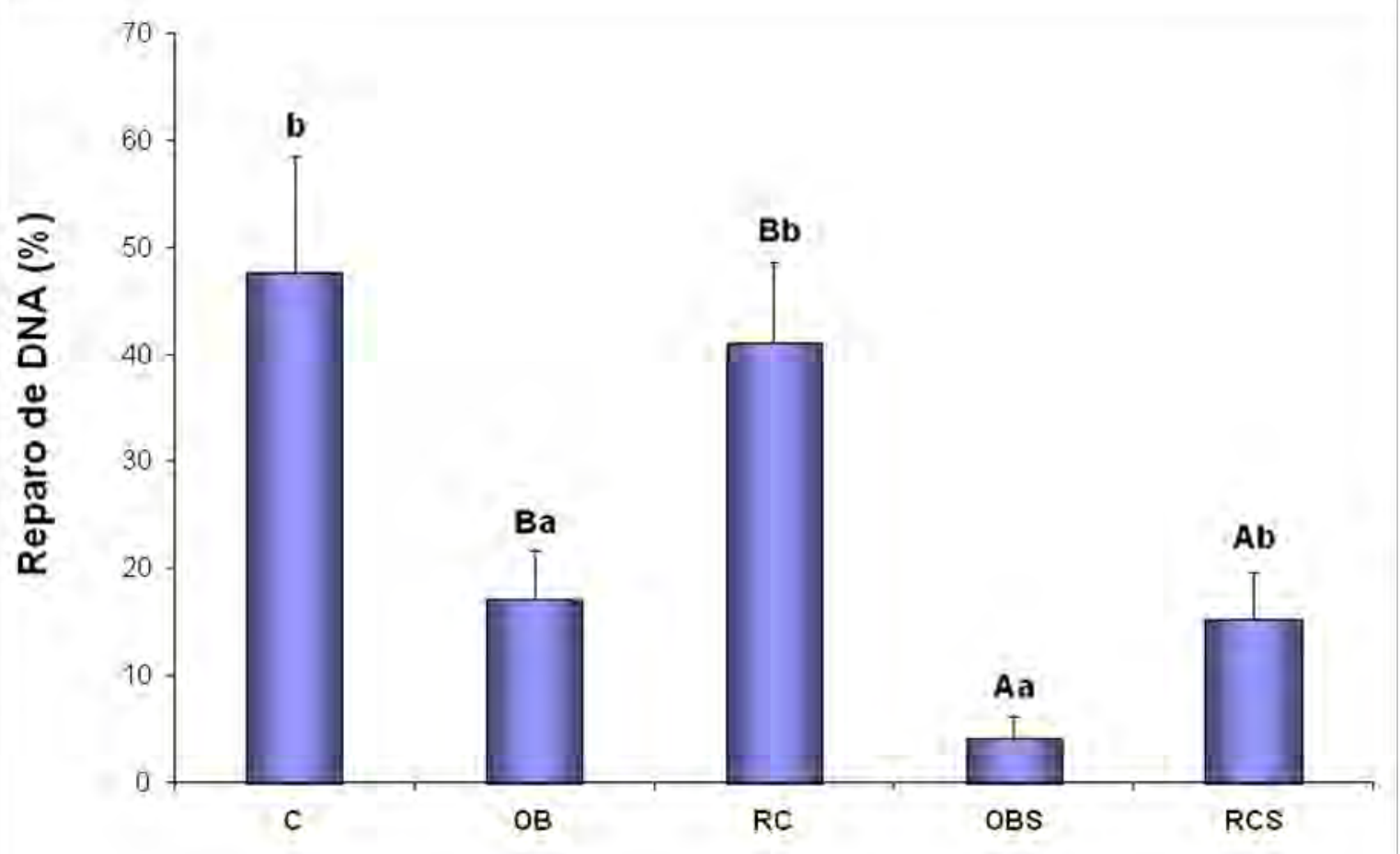

Figura 16- Sistema Reparo. C, controle; OB, obeso; RC, restrição calórica; OBS, obeso com dose de $25 \mu \mathrm{g}$ de Triiodotironina/100g; RCS, restrito com dose de $25 \mu \mathrm{g}$ de Triiodotironina/100g. Dados expressos em média \pm desvio-padrão. Letras maiúsculas, comparações dentro do grupo (OB $\times$ OBS ou RC $\times$ RCS); letras minúsculas, comparações entre os grupos ( $\mathrm{C} \times \mathrm{OB} \times \mathrm{RC}$ ou OBS $\times \mathrm{RCS}$ ); letras iguais $=p>0,05$; letras diferentes $=p<0,05$. 


\section{6- DISCUSSÃO}

A obesidade é um dos maiores problemas enfrentados pela saúde pública na atualidade (GUZIK et al., 2006). No Brasil, as mudanças demográficas, sócioeconômicas e epidemiológicas ao longo do tempo permitiram que ocorresse a denominada transição nos padrões nutricionais, com diminuição progressiva da desnutrição e aumento da obesidade (MONTEIRO et al., 1995; FRANCISCH et al., 2001). Isso se torna um problema de saúde pública, uma vez que as conseqüências da obesidade para a saúde são inúmeras e variam desde o risco aumentado de morte prematura a graves doenças não letais, mas debilitantes, que afetam diretamente a qualidade de vida dos indivíduos.

Ao mesmo tempo restrições calóricas são instituídas para melhorar a qualidade de vida dos indivíduos (Bordone, 2005) e diminuir as comorbidades e o dano de DNA (MASORO, 2005).

Apesar do erro em se instituir hormônios tireoidianos associado a essas dietas ainda muitas vezes pode ser observada essa conduta em prescrições médica.

Estudos sobre as causas e tratamentos da obesidade têm sido desenvolvidos em animais que apresentam esta característica através de alterações endócrinas, anormalidades genéticas e alterações alimentares (SCLAFANI \& SPRINGER, 1976).

Nossos primeiros experimentos foram realizados em animais submetidos à dieta hipercalorica rica em ácidos graxos insaturados para mimetizar o que ocorre em humanos.

Em estudos experimentais, mesmo mantidas as condições laboratoriais, não está assegurado um comportamento homogêneo dos animais. Neste sentido, ratos submetidos às rações normocalórica ou hipercalórica, em modelos de obesidade induzida por dieta, podem apresentar características comuns de respostas (NASCIMENTO, 2008). Assim, erros de classificação podem ocorrer, ou seja, animais submetidos à dieta normocalórica podem ser classificados como controle, quando, na realidade, exibem respostas semelhantes aos animais que se tornaram obesos pela dieta hipercalórica, ou vice-versa. Por esta razão, torna-se necessário estabelecer um critério que possibilite a separação dos animais em controle ou obeso. Estudo em nosso laboratório mostrou que o melhor indicador de obesidade é a adiposidade corporal: contudo, este índice é obtido após a eutanásia do animal (NASCIMENTO, 2008). Entretanto, foi demonstrado que o peso corporal, avaliado in 
vivo, apresenta boa correlação com o índice de adiposidade. Com isso, no presente estudo, os grupos controle e obeso foram constituídos utilizando-se um critério de classificação aplicado sobre o peso corporal, na 20aㅗ semana do estudo.

Primeiramente, caracterizaremos nosso modelo experimental constituído por animais obesos induzidos por dieta rica em ácidos graxos insaturados e submetidos à restrição calórica com e sem associação da dose suprafisiológica de $T_{3}$. Posteriormente, discutiremos os resultados sobre o dano de DNA a esses animais.

Foi demonstrado neste estudo que as dietas hipercalóricas oferecidas aos animais obesos induziu acentuado ganho de peso e adiposidade, quando comparados aos demais grupos (HARRIS,1994; AINSLIE, 2000; ROBERTS, 2002). O consumo de dietas ricas em gordura não aumentam a oxidação de lipídeos na mesma proporção; com isso, há aumento de peso corporal devido à deposição de triacilglicerol no tecido adiposo (TENTOLOURIS, 2008; SCHRAUWEN, 2000). A restrição calórica aplicada, de $25 \%$, foi eficiente em reduzir o peso e a adiposidade dos animais, como descrito em outros estudos (Alonso, 2005; Thompson, 2005; Daly, 2005) e as doses suprafisiológicas de $T_{3}$, tanto nos animais OB como nos RC, diminuíram peso e adiposidade (Tabela 2; Figuras 6 e 7).

Dietas ricas em gordura provocam hiperfagia (Harris,1994; Elliott, 2004), mas os animais do grupo $\mathrm{OB}$, que receberam dieta hipercalórica, consumiram menor quantidade de dieta, porém com ingestão calórica maior que os animais C. Os animais OBS, mesmo apresentando consumo em gramas semelhante ao grupo RCS, mostraram ingestão calórica significativamente elevada. Esses dados são concordantes com a literatura (Gaíva, 2001), que mostrou que dietas ricas em gordura aumentam a secreção de colecistoquinina, hormônio envolvido no processo de saciedade (FRENCH, 1995; HORN, 1996). Estes dados indicam que a eficiência alimentar nos grupos que receberam dietas hipercalóricas foi maior quando comparado com os grupos que receberam dieta padrão (Tabela 3).

Tem sido mostrado que manipulações dietéticas, hormônios e citocinas induzem respostas metabólicas distintas em diferentes depósitos de gordura (POND, 1999). Nossos resultados mostram que dietas ricas em ácidos graxos insaturados aumentam os depósitos de gordura retroperitoneal, visceral e epididimal, mesmo nos grupos tratados com T3 (Figura 6).

Como encontrado neste estudo, alguns trabalhos têm mostrado que dietas ricas em gordura, sem colesterol, não alteram o perfil lipídico (FIELDING, 1995; 
SPADY, 1988). Verificamos um aumento nos níveis de HDL do grupo OB em relação ao RC; isto pode ter ocorrido devido à composição lipídica da dieta utilizada que é rica em ácidos graxos insaturados. Esses dados estão de acordo com os resultados obtidos por Estadella et al., 2004; Cintra et al., 2006, que relataram que o grupo alimentado com dieta rica em lipídeos insaturados apresentou níveis de HDL maiores que o grupo normal.

Os animais OBS apresentaram aumento nos níveis glicêmicos de jejum em relação ao grupo RCS. Entretanto, é relatado que o excesso de hormônio tireoidiano aumenta a glicose plasmática (DIMITRIADIS \& RAPTIS, 2001), confirmando os dados do grupo OBS, mas não do grupo RCS. Possivelmente, o grupo RCS apresentava glicemia de jejum mais baixa pela própria restrição. Contudo a influência exata dos hormônios tireoidianos sobre a sensibilidade da insulina e o metabolismo da glicose ainda é controversa (SETIA, 2007).

Os animais que receberam salina não mostraram diferença para área sob a curva glicêmica. Por outro lado, os animais RCS apresentaram diminuição estatística nos níveis de glicose plasmática em relação aos obesos com hormônio. Usando o índice insulina plasmática/glicose plasmática, foi sugerida uma resistência à insulina para o grupo $\mathrm{OB}$, que demonstram uma associação entre dieta rica em gordura com resistência à insulina (BROWN, 2002; VAN, 2002). Resistência à insulina é a falta de habilidade dos tecidos periféricos responderem apropriadamente a concentrações normais e aumentadas de insulina circulante (ZHAO, 2005). Está bem estabelecido que os hormônios tireoidianos afetam a ação da insulina. A dose suprafisiológica de $25 \mu \mathrm{g}$ de T3 $/ 100 \mathrm{~g}$ de peso do animal aumentou a sensibilidade da insulina em relação aos animais não tratados. Resultado discordante aos encontrados na literatura, os quais mostram que o excesso de HT induz a resistência à insulina (DIMITRIADIS \& RAPTIS, 2001).

Os animais que receberam dieta hipercalórica apresentaram hiperinsulinemia em relação ao grupo $\mathrm{C}$ e ao grupo submetido à restrição calórica, dados corroborados pela literatura (ELLIOTT, 2004; BARNES, 2003). O grupo RC apresentou níveis plasmáticos de insulina similar aos encontrados para o grupo $\mathrm{C}$ (ALONSO, 2005; ELLIOTT, 2004; LEVIN, 2004; WOLFE, 2004). Por outro lado, já foi relatado aumento nos níveis plasmáticos de insulina em animais submetidos à restrição alimentar (STELMASKA, 2004). Da mesma forma que acontece com o grupo OBS, os animais com restrição que receberam dose de $25 \mu \mathrm{g}$ de $\mathrm{T}_{3} / 100 \mathrm{~g}$ de 
peso, apresentaram uma diminuição significante nos níveis plasmáticos de insulina. Demonstrando que o hormônio diminui a resistência a insulina mais que a própria restrição. Isto pode estar associado ao tempo de exposição aos HT, que apesar de não ser suficiente para aumentarem o metabolismo da glicose, foram suficientes para reduzir o tecido adiposo periférico e desta forma diminuir a resistência.

Os resultados para os níveis séricos de leptina apresentaram o mesmo comportamento dos níveis de insulina, ou seja, os animais OB apresentaram hiperleptinemia quando comparados aos demais animais (AINSLIE, 2000; BARNES, 2003; BELL-ANDERSON, 2004; VASSELLI, 2005). A restrição calórica retornou os níveis de leptina aos níveis do grupo C (Elliott, 2004; Levin, 2004; Wolfe, 2004; Viguerie, 2005), e a dose de $25 \mu \mathrm{g}$ de $\mathrm{T}_{3} / 100 \mathrm{~g}$ de peso do animal diminuiu significativamente os níveis de leptina tanto nos animais OBS quanto nos RCS. A leptina pode influenciar a interação entre genética e fatores ambientais, desde que foi mostrado que dietas ricas em gordura causam aumento nos níveis de leptina, e este efeito pode explicar a variabilidade de composição corporal entre indivíduos que consomem dietas similares. Entretanto, o aumento nos níveis de leptina é melhor explicado pelo aumento da gordura corporal (SCHRAUWEN, 2000; WOLFE, 2004; JOHNSTONE, 2005). Estudos experimentais sugerem que a sensibilidade à leptina pode estar sob controle hormonal e nutricional (BENNET, 1998). Näslund et al., (2000) relataram aumento significativo de leptina plasmática em pacientes que ganharam peso comparados com os que perderam peso. Demonstraram que pacientes com alta concentração de leptina por unidade de IMC não podem sustentar a perda de peso durante os programas de restrição alimentar. Contudo, não está claro porque a concentração plasmática de leptina inicial pode predizer o sucesso de programas que visam à perda de peso. Torgerson et al., (1999) sugerem que uma redução nos níveis de leptina em resposta à restrição calórica não parece regular a resposta hormonal à restrição em obesos, mas de certo modo manter a perda de peso.

Enquanto alguns trabalhos relatam que a associação entre a concentração de leptina e HT não foi observada (Näslund, 2000; Torgerson, 1999; Reinerh, 2002), enquanto outros mostram uma correlação negativa (Escobar-Morreale, 1997; Zabrocka, 2006), como ocorreu no nosso estudo.

Apesar de alguns autores encontrarem níveis de $\mathrm{T}_{3}$ aumentados na obesidade (Reinerh, 2002; Krotkiewski, 2002), estes resultados não foram 
reproduzidos em nosso estudo, visto que a dosagem sérica de $T_{3}$ livre foi similar entre os grupos $\mathrm{C}$ e $\mathrm{OB}$. A restrição calórica resultou em diminuição significante nos níveis de $\mathrm{T}_{3}$ livre quando comparado aos animais C (TORGERSON, 1999; REINERH, 2002).

Administração de doses suprafisiológicas de $T_{3}$ aumentaram a concentração sérica de $T_{3}$, mostrando a eficiência da administração hormonal durante 0 experimento. As concentrações séricas de $\mathrm{T}_{4}$ livre e TSH apresentaram níveis semelhantes entre os animais $C$ e OB e diminuição significativa para os animais $R C$. Não houve diferença estatística entre os animais que foram submetidos à restrição calórica sem ou com administração do hormônio. Isto pode evidenciar uma adaptação do organismo para poupar energia, uma vez que $\mathrm{T}_{3}$ é um hormônio metabolicamente ativo que leva à redução da gordura corporal pelo aumento da termogênese e oxidação lipídica (OBREGON, 2008). Para os animais OBS houve diminuição significativa nos níveis de $\mathrm{T}_{4}$ livre e TSH em relação à $\mathrm{OB}$, uma vez que administração exógena de $\mathrm{T}_{3}$ suprimi a secreção endógena de TSH e a produção de $\mathrm{T}_{4}$ pela tireóide (ABEL, 2003).

Desta forma caracterizamos nosso modelo experimental e a eficiência do tratamento com dose supra fisiológica de $\mathrm{T}_{3}$.

Para avaliar danos ao DNA em células individuais, Ostling \& Johanson (1984) desenvolveram um método baseado na eletroforese de células imersas e lisadas em agarose em lâminas de microscopia. O mecanismo avalia que quando a ocorrência de quebras nas fitas do DNA, que é organizado como uma grande estrutura supercoloidal, tornam-as relaxadas e podem, assim, deslizar mais eficientemente na eletroforese. Singh et al. (1988) modificaram esta técnica para permitir uma avaliação de danos ao DNA em células únicas sob condições alcalinas. Esta abordagem otimiza a desnaturação do DNA e permite uma avaliação de quebras de fita-simples e locais álcali-lábeis (TICE et al., 2000).

Ao longo das últimas décadas, o ensaio do cometa tornou-se um dos testes mais utilizados para avaliação de danos no DNA, sendo aplicado para diversas finalidades, como testes de genotoxicidade, biomonitoramento humano, ecogenotoxicologia e estudos fundamentais de danos e reparos no DNA (COLLINS, 2004).

O ensaio cometa oferece uma oportunidade para correlacionar níveis de danos ao DNA induzidos por terapia com a dose administrada e também para 
modular a dose reduzindo danos genotóxicos (SANCHES-SUÁREZ et al., 2008; MIYAMAE et al., 1998).

Como ressaltamos na introdução, o ensaio cometa não é utilizado para detectar mutações, mas sim lesões genômicas que, após serem processadas, podem resultar em mutação. Diferente das mutações, as lesões detectadas por esse Ensaio são passíveis de correção. Assim sendo, o ensaio cometa pode ser também utilizado para estudos de reparo do DNA, (ALBERTINI et al., 2000).

Vários trabalhos indicam a aplicabilidade dos linfócitos para se avaliar os danos oxidativos ao DNA, tendo em vista que estes são excelentes marcadores das condições de saúde do corpo (OLDHAM, 2002). Assim, para este estudo foram utilizados linfócitos para analisar estas lesões em animais obesos e submetidos a restrição alimentar com e sem administração de dose suprafisiológica de HT.

Os dados, aqui apresentados referentes às análises dos linfócitos pelo ensaio cometa mostraram que os grupos submetidos à dieta hipercalórica apresentaram um aumento significante nos níveis de dano de DNA, estando em concordância com a literatura, que mostra que a ingestão de dieta hipercalórica é determinante significativo do dano (PARKS, 2001 \& HENNING, 2001).

O consumo excessivo de gordura total pode estar associado ao aumento nos marcadores de oxidação lipídica (Willet, 2001; Wynder, 1997), enquanto a obesidade leva ao aumento de celulas inflamatórias, que estimulam a formação de EROs e, consequentemente, aos danos de DNA (YAN, 2006).

Os animais que foram submetidos à restrição alimentar apresentaram níveis diminuídos de danos quando comparados com os animais que receberam dietas hipercalóricas, mostrando o mesmo comportamento observados por outros autores (GREDILLA, 2001; ZAINAL, 2000; BARJA, 2004).

O mecanismo pelo qual a restrição calórica diminui a formação das espécies reativas de oxigênio ainda não está claro. No entanto, a RC parece promover melhora nos danos oxidativos, além de melhorar o sistema de reparação do DNA (YU, 2006). Ainda não está estabelecido se a restrição calórica apresenta o mesmo efeito benéfico sobre a longevidade em humanos como é mostrado em estudos animais (HAUTVAST, 1993).

Estudos relatam que concentrações fisiológicas de hormônios tireoidianos não produzem danos genéticos. Por outro lado, concentrações inadequadas desses hormônios podem gerar danos de DNA. (HUDIG, 1997; MAGSINO et al., 2000). Em 
concordância, os animais que receberam a intervenção com dose suprafisiológica (T3) apresentaram um aumento significante nos níveis de danos de DNA quando comparados aos seus respectivos controles. Estudo realizado em cultura celular tratada com $\mathrm{T}_{3}$, mostrou que o hormônio tireoidiano aumenta a taxa metabólica e o consumo de oxigênio, gerando estresse oxidativo e, consequentemente, induzindo dano de DNA (DJELIC, 2003).

Vários estudos têm avaliado os efeitos da indução de danos em DNA, por peróxido de hidrogênio $\left(\mathrm{H}_{2} \mathrm{O}_{2}\right)$, para verificar a capacidade que as células teriam em se proteger após o desafio com $\mathrm{H}_{2} \mathrm{O}_{2}$. (FESTA et al., 2001; SHI et al., 2002).

Em relação ao efeito protetor contra danos oxidativos ao DNA induzidos por peróxido de hidrogênio, os nossos resultados que a intervenção com restrição calórica foi capaz de minimizar os danos gerados de maneira significativa (YU, 2006). Contudo, quando administrada dose suprafisiológica de $T_{3}$ nesses animais, ocorreu uma redução na eficiência de reparo; entretanto, esse grupo apresentou menor dano quando comparado ao grupo que recebeu dieta hipercalórica.

Sabe-se que a obesidade (Yan, 2006) e concentrações inadequadas o hormônios tireoidianos (HUDIG, 1997; MAGSINO et al., 2000) podem gerar danos de DNA, porém dados da literatura ainda são escassos quanto ao sistema reparo. No presente estudo, os animais obesos apresentaram menores níveis de reparo do DNA quando comparados aos grupos que receberam dieta hipocalórica. Apesar disso, os animais que receberam dose suprafisiológica de $25 \mu \mathrm{g}$ de Triiodotironina $/ 100 \mathrm{~g}$, apresentaram diminuição significante no reparo quando comparados aos grupos que não receberam tratamento. 


\section{7- CONCLUSÃO}

A dieta utilizada neste estudo, rica em Ácidos Graxos insaturados (AGI), ocasionou obesidade e provocou dano de DNA. A dose supra fisiológica de $T_{3}$, administrada em animais $\mathrm{OB}$, reduziu o peso corporal e a adiposidade, entretanto potencializou a produção de danos de DNA nestes animais.

A restrição alimentar minimizou os efeitos da obesidade, diminuindo peso, adiposidade e as lesões de DNA no grupo tratado com salina. Contudo, não foi eficiente em reduzir os danos causados pela administração de triiodotironina, mostrando que o hormônio tireoidianos em altas doses leva a lesão de DNA independente da dieta. 


\section{8- REFERÊNCIAS BIBLIOGRÁFICAS*}

Abel ED, Moura EG, Ahima, RS, Campos-Barros A, Pazos-Moura CC, Boers M, et al. Dominant inhibition of thyroid hormone action selectively in the pituitary of thyroid hormone receptor- $\beta$ null mice abolishes the regulation of thyrotropin by thyroid hormone. Mol Endocrinol. 2003;17(9):1767-76.

Ainslie DA, Proietto J, Fam BC, Thorburn AW. Short-term, high-fat diets lower circulating leptin concentrations in rats. Am J Clin Nutr. 2000;71(2):438-42.

Albertini RJ, Anderson D, Douglas GR, Hagmar L, Hemmink K, Merlo F, et al. IPCS guidelines for the monitoring of genotoxic effects of carcinogens in humans. Mutat Res. 2000;463(2):111-72.

Alonso A, Fernández Y, Fernández R, Ordóñez P, Moreno M, Díaz F, et al. Effect of food restriction on the insulin signalling pathway in rat skeletal muscle and adipose tissue. J Nutr Biochem. 2005;16(10):602-9.

Ames BN. Dietary carcinogens and anticarcinogens. Oxygen radicals and degenerative diseases. Science. 1983;221(4617):1256-64.

Ames BN. Mutagenesis and carcinogenesis: endogenous and exogenous factors. Environ Mol Mutagen. 1989; 14 Suppl 16:S66-77.

Aruoma OI. Nutrition and health aspects of free radicals and antioxidants. Food ChemToxicol. 1994;32(7):671-83.

Barja G. Free radicals and aging. Trends Neurosci. 2004;27(10):595-600.

\footnotetext{
* International Committee of Medical Journal Editors. Uniform Requirements for Manuscripts Submitted to Biomedical Journal: sample references [Internet]. Bethesda: U.S. National Library of Medicine; 2003 [last updated 2009 May 14]. Available from:http://www.nlm.nih.gov/bsd/uniform_requirements.html National Library of Medicine. List of journals indexed in Index Medicus. Washington; 2003. 240p.
} 
Barnes MJ, Lapanowski K, Conley A, Rafols JÁ, Jen KLC, Dunbar JC. High fat feeding is associated with increased blood pressure, sympathetic nerve activity and hypothalamic mu opioid receptors. Brain Res Bull. 2003;61(5):511-9.

Bell-Anderson KS, Bryson JM. Leptin as a potencial treatment for obesity. Treat Endocrinol. 2004;3(1):11-8.

Bennet PA, Lindell K, Karlsson C, Robinson ICAF, Carlsson LMS, Carlsson B. Differential expression and regulation of leptin receptor isoforms in the rat brain: effects of fasting and oestrogen. Neuroendocrinology. 1998;67(1):29-36.

Bernstein C, Bernstein H. Aging, sex, and DNA repair. New York: Academic Press; 1991. p.15-25.

Bordone L, Guarente L. Calorie restriction, SIRT1 and metabolism: understanding longevity. Nat Rev Mol Cell Biol; 2005;6(4):298-305.

Boustany CM, Bharadwaj K, Daugherty A, Brown DR, Randall DC, Cassis LA. Activation of the systemic and adipose renin-angiotensin system in rats with dietinduced obesity and hypertension. Am J Physiol Regul Integr Comp Physiol. 2004;287(4):R943-9.

Brown JL, Spicer MT, Spicer LJ. Effect of high-fat diet on body composition and hormone responses to glucose tolerance test. Endocrine. 2002;19(3):327-32.

Cerutti PA. Oxy-radicals and cancer. Lancet. 1994;344(8926):862-3.

Cintra DEC, Costa AGV, Peluzio MCG, Matta SLP, Silva MTC, Costa NMB. Lipid profile of rats fed high-fat diets based on flaxseed, peanut, trout, or chicken skin. Nutrition. 2006;22(2):197-205.

Claret M, Corominola H, Canals I, Nadal B, Chavanieu A, Pfeiffer B, et al. S 23521 decreases food intake and body weight gain in diet-induced obese rats. Obes Res. 2004;12(10):1596-603. 
Collins AR. The comet assay for DNA damage and repair: principles, applications, and limitations. Mol Biotechnol. 2004;26(3):249-61.

Collins AR, Raslova K, Somorovska M, Petrovska H, Ondrusova A, Vohnout B, et al. DNA damage in diabetes: correlation with a clinical marker. Free Radic Biol Med. 1998;25(3):373-7.

Dahlman I, Linder K, Arvidsson Nordström E, Andersson I, Lidén J, Verdich C, et al. Changes in adipose tissue gene expression with energy-restricted diets in obese women. Am J Clin Nutr. 2005;81(6):1275-85.

Daly ME, Paisey R, Millward BA, Eccles C, Williams K, Hammersley S, et al. Shortterm effects of severe dietary carbohydrate-restriction advice in type 2 diabetes - a randomized controlled trial. Diabet Med. 2005;23(1):15-20.

Demirbag R, Yilmaz R, Kocyigit A. Relationship between DNA damage, total antioxidant capacity and coronary artery disease. Mutat Res. 2004;570(2):197-203.

Dimitriadis GD, Raptis SA. Thyroid hormone excess and glucose intolerance. Exp Clin Endocrinol Diabetes. 2001;109 Suppl 2:S225-39.

Djelic N, Anderson D. The effect of the antioxidant catalase on oestrogens, triiodothyronine, and noradrenaline in the Comet assay. Teratog Carcinog Mutagen. 2003;23 Suppl 2:69-81.

Doll R, Peto R. The cause of cancer: quantitative estimates of avoidance risk of cancer in the United States today. J Natl Cancer Inst. 1981;66(6):1191-308.

Dunn CL, Hannan PJ, Jeffery RW, Sherwood NE, Pronk NP, Boyle, R. The comparative and cumulative effects of a dietary restriction and exercise on weight loss. Int J Obes. 2006;30(1):112-21. 
Elliott JC, Harrold JA, Brodin P, Enquist K, Bäckman A, Byström M, et al. Increases in melanin-concentrating hormone and $\mathrm{MCH}$ receptor levels in the hypothalamus of dietary-obese rats. Mol Brain Res. 2004;128(2):150-9.

Escobar-Morreale HF, Rey FE, Escobar GM. Thyroid hormones influence serum leptin concentrations in the rat. Endocrinology. 1997;138(10):4485-8.

Estadella D, Oyama LM, Dâmaso AR, Ribeiro EB, Nascimento CMO. Effect of palatable hyperlipidic diet on lipid metabolism of sedentary and exercised rats. Nutrition. 2004;20(2):218-24.

Fernández-Galaz C, Fernández-Agulló T, Pérez C, Peralta $S$, Arribas $C$, Andrés A, et al. Long-term food restriction prevents ageing-associated central leptin resistance in wistar rats. Diabetologia. 2002;45(7):997-1003.

Festa F, Aglitti, T, Duranti G, Ricordy R, Perticone P, Cozzi R. Strong antioxidant activity of ellagic acid in mammalian cells in vitro revealed by the comet assay. Anticancer Res. $2001 ; 21(6 \mathrm{~A}): 3903-8$.

Fielding CJ, Havel RJ, Todd KM, Yeo KE, Schioetter MC, Weinberg V, et al. Effects of dietary cholesterol and fat saturation on plasma lipoproteins in an ethnically diverse population of health young men. J Clin Invest. 1995;95(2):611-8.

Finer N. Low-calorie diets and sustained weight loss. Obes Res. 2001;9 Suppl 4:S290-4.

Forster MJ, Morris P, Sohal RS. Genotype and age influence the effect of caloric intake on mortality in mice. FASEB J. 2003;17(6):690-2.

Fortini P, Pascucci B, Parlanti E, D'errico M, Simonelli V, Dogliotti E. 8-Oxoguanine DNA damage: at the crossroad of alternative repair pathways. Mutat Res. 2003;531(1-2):127-39. 
Francisch RP, Pereira LO, Lancha Junior AH. Exercício, comportamento alimentar e obesidade: revisão dos efeitos sobre a composição corporal e parâmetros metabólicos. Rev Paul Educ Fis. 2001;15(2):117-40.

French SJ, Murray B, Rumsey RDE, Fadzlin R, Read NW. Adaptation to high-fat diets: effects on eating behaviour and plasma colecystokinin. $\mathrm{Br} J$ Nutr. 1995;73(2):179-89.

Frei B. Reactive oxygen species and antioxidant vitamins: mechanisms of action. Am J Med. 1994;97 Suppl 3A:S5-13.

Gaíva MHG, Couto RC, Oyama LM, Couto GEC, Silveira VLF, Ribeiro EB, et al. Polyunsaturated fatty acid-rich diets: effect on adipose tissue metabolism in rats. $\mathrm{Br}$ J Nutr. 2001;86(3):371-7.

Giannocco G, Santos RA, Nunes MT. Thyroid hormone stimulates myoglobin gene expression in rat cardiac muscle. Mol Cell Endocrinol. 2004;226(1-2):19-26.

Giovanelli L, Saieva C, Masala G, Testa G, Salvini S, Pitozzi V, et al. Nutritional and lifestyle determinants of DNA oxidative damage? A study in a Mediterranean population. Carcinogenesis. 2002;23(9):1483-9.

Gredilla R, Barja G, López-Torres M. Effect of short-term caloric restriction on $\mathrm{H} 2 \mathrm{O} 2$ production and oxidative DNA damage in rat liver mitochondria and location of the free radical source. J Bioenerg Biomembranes. 2001;33(4):279- 87.

Guzik TJ, Mangalat D, Korbut R. Adipocytokines - novel link between inflammation and vascular function? J Physiol Pharmacol. 2006;57(4):505-28.

Halliwell B. Free radicals and antioxidants: a personal view. Nutr Rev. $1994 ; 52(8): 253-65$.

Halliwell B, Gutteridge JMC. Free radicals in biology and medicine. $3^{\text {rd }}$ ed. Oxford: University Press; 1999. 
Harris RBS. Factors influencing energy intake of rats fed either a high-fat or a fat mimetic diet. Int J Obes Relat Metab Disord. 1994;18(9):632-40.

Hautvast JG. The future of nutrition in Europe. Eur J Clin Nutr.1993;47 Suppl 1:S96100.

Hennig B, Toborek M, McClain CJ. High-energy diets, fatty acids and endothelial cell function: implications for atherosclerosis. J Am Coll Nutr. 2001; 20 Suppl 2:S97-105.

Higginson J. Changing concepts in cancer prevention: Limitations and implications for future research in environmental carcinogenesis. Cancer Res.1988;48:1381-89.

Hoeijmakers JH. Genome maintenance mechanisms for preventing cancer. Nature. 2001;411(6835):366-74.

Horn C, Tordoff MG, Friedman MI. Does ingested fat produce satiety? Am J Physiol Regul Integr Comp Physiol. 1996;270(4):R761-5.

Hudig F, Bakker O, Wiersinga WM. Tri-iodothyronine prevents the aniodaroneinduced decrease in the expressionof the liver density lipoprotein receptor gene. $\mathrm{J}$ Endocrinol. 1997;152(3):413-21.

Jain AK. Preliminary study on the desmutagenic and antimutagenic effect on some products. Curr Sci.1987;56:1266-8.

Johnstone AM, Murison SD, Duncan JS, Rance KA, Speskman JR. Factors influencing in basal metabolic rate include fat-free mass, fat mass, age, and circulating thyroxine but not sex, circulating leptin, or triiodothyronine. Am J Clin Nutr. 2005;82(5):941-8.

Kautzky-Willer A, Ludwig C, Nowotony P, Roden A, Huemer C, Widhalm K, et al. Elevation of plasma leptin concentrations in obese hyperinsulinaemic hypothyroidism before and after treatment. Eur J Clin Invest. 1999;29:395-403. 
Kim MS, Small CJ, Stanley SA, Morgan DGA, Seal LJ, Kong WM, et al. The central melanocortin system affects the hypothalamopituitary thyroid axis and may mediate the effect of leptin. J Clin Invest. 2000;105(7):1005-11.

King JS, Philips JW, Morgan WF. The role DNA double strand break rejoining in chromosome damage in repair. In: Obe G, Natarajan AT. Chromosomal alterations. Berlin: Springer-Verlag; 1994. p.65-75.

Krotkiewski M. Thyroid hormones in the pathogenesis and treatment of obesity. Eur J Pharmacol. 2002;440(2):85-98.

Levin BE, Dunn-Meynell AA. Chronic exercise lowers the defended body weight gain and adiposity in diet-induced obese rats. Am J Physiol Regul Integr Comp Physiol. 2004;286(4):R771-8.

Levin BE, Dunn-Meynell AA. Reduced central leptin sensitivity in rats with dietinduced obesity. Am J Physiol Regul Integr Comp Physiol. 2002;283(4):R941-8.

Lili A, Barouch DG, Lei C, Karen L, Miller WX, Alexander C, et al. Cardiac myocyte apoptosis is associated with increased DNA damage and decreased survival in murine models of obesity. Circ Res. 2006;98(1):119-24.

Lonnqvist F, Nordfors L, Schalling M. Leptin and its potential role in human obesity. J Intern Med. 1999;245(6):643-52.

López-Torres M, Gredilla R, Sanz A, Barja G. Influence of aging and long-term caloric restriction on oxygen radical generation and oxidative DNA damage in rat liver mitochondria. Free Radic Biol Med. 2002;32(9):882-9.

Magsino Junior C, Hamouda W, Ghanim H, Browne R, Aljada A, Dandona P. Effect of triiodothyronine on reactive oxygen species generation by leukocytes, indices of oxidative damage, and antioxidant reserve. Metabolism. 2000; 49(6):799-803. 
Masoro EJ. Overview of caloric restriction and ageing. Mech Ageing Dev. 2005;126(9):913-22.

Maza M, Olivares D, Hirsch S, Sierralta W, Gattas V, Barrera G, et al. Weight increase and overweight are associated with DNA oxidative damage in skeletal muscle. Clin Nutr. 2006;25(6):968-76.

Miyamae Y, Zaizen K, Ohara K, Mine Y, Sasaki Y. Detection of DNA lesions induced by chemical mutagens by the single cell electrophoresis (comet) assay: relationship between the onset of DNA damage and the characteristics of mutagens. Mutat Res. 1998;415(3):229-35.

Monteiro CA, Mondini L, Souza ALM, Popkin BM. Da desnutrição para a obesidade: a transição nutricional no Brasil. In: Monteiro CA, organizador. Velhos e novos males da saúde no Brasil: a evolução do país e de suas doenças. São Paulo: Hucitec; 1995. p.247-55.

Nascimento AF, Sugizaki MM, Leopoldo AS, Lima-Leopoldo AP, Nogueira CR, Novelli EL, et al. Misclassification probability as obese or lean in hypercaloric and normocaloric diet. Biol Res. 2008;41(3):253-9.

Näslund E, Andersson I, Degerblad M, Kogner P, Kral JG, Rössner S, et al. Associations of leptin, insulin resistance and thyroid function with long-term weight loss in dieting obese men. J Intern Med. 2000;248(4):299-308.

Obregon MJ. Thyroid economy: regulation, cell biology, thyroid hormone metabolism and action: the special edition: metabolic effects of thyroid hormone. Thyroid. 2008;18(2):185-95.

O'Brien PE, Dixon JB. The extent of the problem of obesity. Am J Surg. 2002; 184(6B):4S-8. 
Oldham KM, Wise SR, Chen L, Stacewicz-Sapuntzakis M, Burns J, Bowen PE. A longitudinal evaluation of oxidative stress in trauma patients. JPEN J Parenter Enteral Nutr. 2002;26(3)189-97.

Ostling $\mathrm{O}$, Johanson KJ. Microeletroforetic study of radiation-induced DNA damages in individual mammalian cells. Biochem Biophys Res Commun. 1984;123(1):291-8.

Parks EJ. Recent findings in the study of postprandial lipemia. Curr Atheroscler Rep. $2001 ; 3(6): 462-70$.

Pinkney JH, Goodrick SJ, Katz J, Johnson AB, Lightman SL, Coppack SW, et al. Leptin and the pituitary - thyroid axis: a comparative study in lean, obese, hypothyroid and hyperthyroid subjects. Clin Endocrinol. 1998;49(5):583-8.

Pond CM. Physiological specialization of adipose tissue. Prog Lipid Res. 1999; 38(3):225-48.

Reinerh T, Andler W. Thyroid hormones before and after weight loss in obesity. Arch Dis Child. 2002;87(4):320-6.

Ribeiro LR, Salvadori DMF, Marques EK. Mutagênese ambiental. Canoas: Ed Ulbra; 2003. p. 355.

Roberts CK, Barnard RJ, Liang KH, Varizi ND. Effect of diet on adipose tissue and skeletal muscle VLDL receptor and LPL: implications for obesity and hyperlipidemia. Atherosclerosis. 2002;161(1):133-41.

Rogers P, Webb GP. Estimation of body fat in normal and obese mice. Br J Nutr. 1980;43(1):83- 6 .

Sánchez-Suárez P, Ostrosky-Wegman P, Gallegos-Hernández F, Peñarroja-Flores R, Toledo-García J, Bravo JL, et al. DNA damage in peripheral blood lymphocytes in patients during combined chemotherapy for breast cancer. Mutat Res. 2008;640(12):8-15. 
Sanz A, Caro P, Ibañez J, Gómez J, Gredilla R, Barja G. Dietary restriction at old age lowers mitochondrial oxygen radical production and leak at complex $\mathrm{I}$ and oxidative DNA damage in rat brain. J Bioenerg Biomembranes. 2005; 37(2):83-90.

Saul RL, Ames BN. Background levels of DNA damage in the population In: Simici MG, Grossman L, Upton AC. Mechanisms of DNA damage and repair: implications for carcinogenesis and risk assessment: New York: Plenum Publishing Corporation;1986. p.529-36.

Schrauwen P, Westerterp KR. The role of high-fat diets and physical activity in the regulation of body weight. Br J Nutr. 2000;84(4):417-27.

Sclafani A, Springer D. Dietary obesity in adult rats: similarities to hypothalamic and human obesity syndromes. Physiol Behav. 1976;17(3):461-71.

Setia S, Sridhar MG, Koner BC, Bobby Z, Bhat V, Chaturvedula L. Increased insulin sensitivity in intrauterine growth retarded newborns - Do thyroid hormones play a role? Clin Chim Acta. 2007;376(1-2):37-40.

Shi YL, James AE, Benzie IF, Buswell JA. Mushroom-derived preparations in the prevention of $\mathrm{H} 2 \mathrm{O} 2$-induced oxidative damage to cellular DNA. Teratog Carcinog Mutagen. 2002;22(2):103-11.

Singh NP, Mccoy MT, Tice RR, Schneider EL. A simple technique for quantitation of low levels of DNA damage in individual cells. Exp Cell Res. 1988;175(1):184-91.

Spady DK, Dietschy JM. Interaction of dietary cholesterol and triglycerides in the regulation of hepatic low density lipoprotein transport in the hamster. J Clin Invest. 1988;81(2):300-9.

Stelmaska E, Korczynska J, Swierczynski J. Tissue-specific effect of refeeding after short and long-term caloric restriction on malic enzyme gene expression in rats tissues. Acta Biochim Pol. 2004;51(3):805-14. 
Storey KB. Oxidative stress: animal adaptations in nature. Braz J Med Biol Res. 1996;29(12):1715-33.

Strychar I. Diet in the management of weight loss. Can Med Assoc J. 2006; 174(1):56-63.

Stuart JA, Karahalil B, Hogue BA, Souza-Pinto NC, Bohr VA. Mitochondrial and nuclear DNA base excision repair are affected differently by caloric restriction. FASEB J. 2004;18(3):595-7.

Surwit RS, Feinglos MN, Rodin J, Sutherland A, Petro AE, Opara EC, et al. Differential effects of fat and sucrose on the development of obesity and diabetes in C57BL/6J and A/J mice. Metabolism. 1995;44(5):645-51.

Takahashi R, Goto S. Effect of dietary restriction beyond middle age: accumulation of altered proteins and protein degradation. Microsc Res Tech. 2002;59(4):278-81.

Tazima $\mathrm{Y}$, Kondo S, Kuroda $\mathrm{Y}$, editors. Problems of threshold in chemical mutagenesis. Tokyo: The Environmental Mutagen Society of Japan Cancer; 1984. p.1970-84.

Tentolouris N, Pavlatos S, Kokkinos A, Perrea D, Pagoni S, Katsilambros N. Dietinduced thermogenesis and substrate oxidation are not different between lean and obese women after two different isocaloric meals, one rich in protein and one rich in fat. Metabolism. 2008;57(3):313-20.

Terzoudi GI, Pantelias GE. Conversion of DNA damage into chromosome damage in response to cell cycle regulation of chromatin condensation after irradiation. Mutagenesis. 1997;14(4):271-6.

Thompson WG, Holdman NR, Janzow DJ, Slezak JM, Morris KL, Zemel MB. Effect of energy-reduced diets high in dairy products and fiber on weight loss in obese adults. Obes Res. 2005;13(8):1344-53. 
Tice RR, Agurell E, Anderson D, Burlinson B, Hartmann A, Kobayashi H, et al. Single cell gel/comet assay: Guidelines for in vitro and in vivo genetic toxicology testing. Environ Mol Mutagen. 2000;35(3):206-21.

Torgerson JS, Carlsson B, Stenlöf K, Carlsson LMS, Bringman E, Sjöström L. A low serum leptin level at baseline and a large early decline in leptin predict a large 1-year weight reduction in energy-restricted obese humans. J Clin Endocrinol Metab. 1999;84(11):4197-203.

Totter JR. Spontaneous cancer and is possible relationship to oxygen metabolism. Proc Natl Acad Sci USA. 1980;77(4):1763-67.

Turrens JF, Alexandre A, Lehninger AL. bisemiquinoe is the electron donor for superoxide formation by complex III of heart mitochondria. Arch Biochem Biophys. 1985;237(2):408-14.

Van Dam RM, Willett WC, Rimm EB, Stampfer MJ, Hu FB. Dietary fat and meat intake in relation to risk of type 2 diabetes in men. Diabetes Care. 2002;25(3):41724.

Vasselli JR, Weindruch R, Heymsfield SB, Pi-Sunyer FX, Boozer CN, Yi N, et al. Intentional weight loss reduces mortality rate in a rodent model of dietary obesity. Obes Res. 2005;13(4):693-702.

Viguerie N, Vidal H, Arner P, Holst C, Verdich C, Avizou S, et al. Adipose tissue gene expression in obese subjects during low-fat and high-fat hypocaloric diets. Diabetologia. 2005;48(1):123-31.

Wanagat J, Allison D, Weindruch R. Caloric Intake and aging: mechanisms in rodents and a study in nonhuman primates. Toxicol Sci. 1999;52 Suppl 2:35-40.

Weiss EC, Galuska DA, Khan LK, Serdula MK. Weight-Control practices among US adults, 2001-2002. Am J Prev Med. 2006;31(1):18-24. 
Willet WC. Diet and breast cancer. J Intern Med. 2001;249(5):395-411.

Wolfe BE, Jimerson DC, Orlova C, Mantozoros CS. Effect of dieting on plasma leptin, soluble leptin receptor, adiponectin and resistin levels in healthy volunteers. Clin Endocrinol. 2004;61(3):332-8.

Wynder EL, Cohen LA, Muscat JE, Winters B, Dwyer JT, Blackburn G. Breast cancer: weighing the evidence for a promoting role of dietary fat. J Natl Cancer Inst. 1997;89(11):766-75.

Yan B, Wang H, Rabbani ZN, Zhao Y, Li W, Yuan Y, et al. Tumor necrosis factoralpha is a potent endogenous mutagen that promotes cellular transformation. Cancer Res. 2006;66(24):11565-70.

Yu BP. Why calorie restriction would work for human longevity. Biogerontology. 2006;7(3):179-82.

Zabrocka L, Klimek J, Swierczynski J. Evidence that triiodothyronine decreases rat serum leptin concentration by down-regulation of leptin gene expression in white adipose tissue. Life Sci. 2006;79(11):1114-20.

Zainal TA, Oberley TD, Allison DB, Szweda LI, Weindruch R. Caloric restriction of rhesus monkeys lowers oxidative damage in skeletal muscle. FASEB J. 2000;14(12):1825-36.

Zhao R, Li Q, Xiao B. Effect of Lycium barbarum polisaccharide on the improvement of insulin resistance in NIDDM rats. Yakugaku Zasshi. 2005; 125(12):981-8. 


\section{9- ANEXOS}

\section{ANEXO 01}

\section{Universidade Estadual Paulista Faculdade de Medicina de Botucatu \\ Distrito Rubião Junior, $s / n^{\circ}-$ Botucatu - S.P. \\ CEP: $18.618-970$ \\ Fone/Fax: (0xx14) 6802-6143 \\ e-mail secretaria: capellup@fmb.unesp.br \\ Instituida na Faculdade de Medicina através da Portaria do Diretor $n^{0} 30$ de 26/04/99

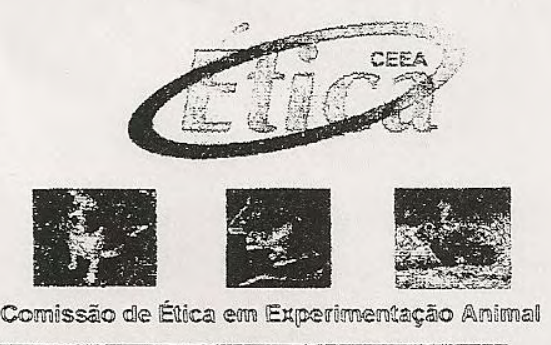

\section{CERTIFICADO}

CERTIFICAMOS que o Protocolo n. ${ }^{\circ} 648$ sobre o Projeto de Pesquisa "Influência do hormônio tireoidiano e da restriçāo alimentar sobre dano de DNA em ratos obesos", a ser conduzido por Maria Tereza De Síbio, orientada pela Profa. Dr. ${ }^{a}$ Célia Regina Nogueira, com a colaboração de Renata de Azevedo Melo Luvizotto, está de acordo com os Princípios Éticos na Experimentação Animal adotado pelo Colégio Brasileiro de Experimentação Animal (COBEA) com a ressalva que os "ratos" são provenientes de Biotério convencional, sem condições de certificar a sanidade dos mesmos.

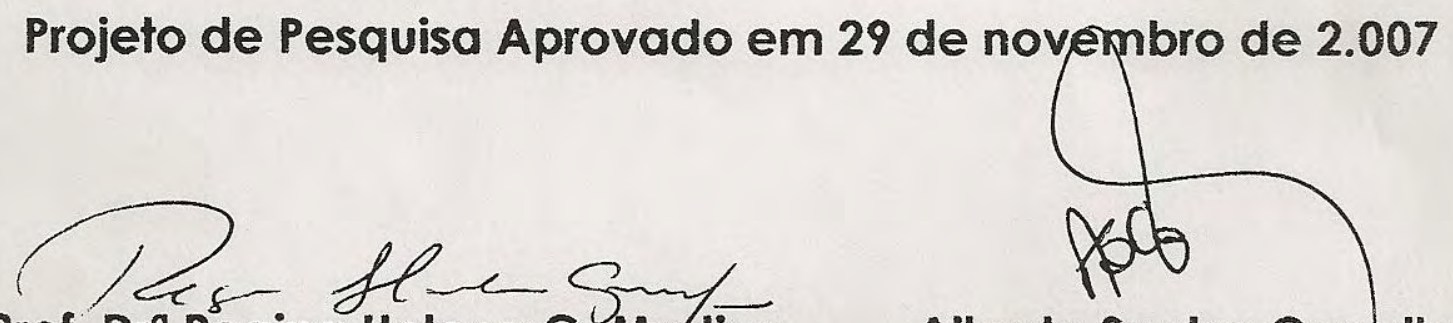

Prof. Dr Regina Helena G. Martins Presidente da CEEA

Alberto Santos Capelluppi Secretório da CEEA 


\section{ANEXO 02 \\ Dosagem de Leptina Plasmática - kit ELISA}

Acondicionar os reagentes em temperatura ambiente antes do início do procedimento.

1. Diluir o Wash Buffer 10 vezes, diluindo todo o conteúdo do recipiente em $900 \mathrm{ml}$ de água deionizada ou destilada.

2. Lavar cada well 3 vezes com $300 \mathrm{ml}$ de Wash Buffer já diluído, por lavagem. Remover o Wash Buffer por inversão da placa e bater a placa sobre papel toalha várias vezes. Não permitir que os wells sequem antes do próximo passo. Se for utilizado lavador automático, seguir as instruções do fabricante para todos os passos de lavagem descritos no protocolo.

3. Adicionar $30 \mu \mathrm{l}$ de Assay Buffer nos wells do Branco, Padrões, Controle de Qualidade 1 (CQ1) e Controle de Qualidade 2 (CQ2). Adicionar $40 \mu \mathrm{l}$ de Assay Buffer nos wells das amostras.

4. Se as amostras forem soro ou plasma, adicionar $10 \mu \mathrm{l}$ de Matrix Solution nos wells de Branco, Padrões, CQ1 e CQ2. Se as amostras forem livres de componentes do soro, adicionar $10 \mu \mathrm{l}$ de Assay Buffer ao invés de Matrix Solution.

5. Adicionar $10 \mu \mathrm{l}$ de Assay Buffer no well do Branco e adicionar em duplicata $10 \mu \mathrm{l}$ dos Padrões de Leptina para Ratos em ordem crescente de concentração nos wells apropriados.

6. Adicionar $10 \mu \mathrm{l}$ de CQ1 e $10 \mu \mathrm{l}$ de CQ2 nos wells apropriados.

7. Adicionar sequencialmente $10 \mu \mathrm{l}$ das amostras em duplicata no restante dos wells.

8. Transferir Antiserum Solution para um suporte e adicionar $50 \mu \mathrm{l}$ desta solução em cada well com uma pipeta multicanal. Cobrir a placa com o papel adesivo e incubá-la a temperatura ambiente por 2 horas em um shaker de placas em rotação moderada, de 400 a $500 \mathrm{rpm}$.

9. Remover o adesivo e descartar a solução. Bater a placa invertida para retirar o excesso de solução de cada well.

10. Lavar os wells 3 vezes com Wash Buffer diluído, $300 \mathrm{ml}$ por well por lavagem. Descartar a solução e bater a placa sobre papel toalha para remover toda a solução, após cada lavagem. 
11. Adicionar $100 \mu \mathrm{l}$ de Detection Antibody em cada well. Cobrir a placa com o adesivo e incubá-la com rotação moderada a temperature ambiente por 1 hora.

12. Remover o adesivo e descartar a solução da placa. Bater a placa invertida para retirar o excesso de solução de cada well.

13. Lavar cada well 3 vezes com Wash Buffer diluído, $300 \mu$ por well por lavagem. Descartar a solução e bater a placa sobre papel toalha para remover toda a solução, após cada lavagem.

14. Adicionar $100 \mu \mathrm{l}$ de Enzyme Solution em cada well. Cobrir a placa com 0 adesivo e incubá-la a com rotação moderada a temperatura ambiente por 30 minutos.

15. Remover o adesivo e descartar a solução da placae. Bater a placa invertida para retirar o excesso de solução de cada well.

16. Lavar cada well 6 vezes com Wash Buffer diluído, $300 \mu$ por well por lavagem.Descartar a solução e bater a placa sobre papel toalha para remover toda a solução, após cada lavagem.

17. Adicionar $100 \mu \mathrm{l}$ de Substrate solution em cada well, cobrir a placa com o adesivo e incubá-la com rotação moderada por aproximadamente 10 a 15 minutos. A coloração azul deverá ser formada nos wells dos padrões de Leptina com intensidade proporcional a concentração de Leptina.

NOTA: Esteja ciente que a coloração pode aparecer mais rapidamente ou demoradamente que o tempo de incubação recomendado dependendo da temperatura do ambiente. Monitorar visualmente a formação da cor para otimizar o tempo de incubação. A formação da cor pode ser monitorada usando um filtro 370 nm, se disponível no espectofotometro. Quando a absorbância está entre 1.2 e 1.8 a $370 \mathrm{~nm}$, a Stop Solution pode ser adicionada para terminar a formação da cor.

18. Remover o adesivo e adicionar $100 \mu \mathrm{l}$ de Stop Solution [Cuidado: Solução Corrosiva] e misturar com a mão. A cor azul deverá se tornar amarela após a acidificação. Ler na asorbência de 450nm e 590nm dentro de 5 minutes e verificar se não existe bolhas de ar em nenhum well. Registre a diferença das unidades de absorbência. 


\begin{abstract}
ANEXO 03
Dosagem de Insulina Plasmática - kit ELISA

Acondicionar os reagentes em temperatura ambiente antes do início do procedimento.
\end{abstract}

1. Diluir o Wash Buffer 10 vezes, diluindo todo o conteúdo do recipiente em $900 \mathrm{ml}$ de água deionizada ou destilada.

2. Lavar cada well 3 vezes com $300 \mathrm{ml}$ de Wash Buffer já diluído, por lavagem. Remover o Wash Buffer por inversão da placa e bater a placa sobre papel toalha várias vezes. Não permitir que os wells sequem antes do próximo passo. Se for utilizado lavador automático, seguir as instruções do fabricante para todos os passos de lavagem descritos no protocolo.

3. Adicionar $10 \mu \mathrm{l}$ de Assay Buffer nos wells do Branco, Padrões, Controle de Qualidade 1 (CQ1) e Controle de Qualidade 2 (CQ2). Adicionar $40 \mu \mathrm{l}$ de Assay Buffer nos wells das amostras.

4. Se as amostras forem soro ou plasma, adicionar $10 \mu \mathrm{l}$ de Matrix Solution nos wells de Branco, Padrões, CQ1 e CQ2. Se as amostras forem livres de componentes do soro, adicionar $10 \mu \mathrm{l}$ de Assay Buffer ao invés de Matrix Solution.

5. Add in duplicate $10 \mathrm{~m}$ I Rat Insulin Standards in the order of ascending concentration to the appropriate wells.

6. Adicionar $10 \mu \mathrm{l}$ de CQ1 e $10 \mu \mathrm{l}$ de CQ2 nos wells apropriados.

7. Adicionar sequencialmente $10 \mu \mathrm{l}$ das amostras em duplicata no restante dos wells.

8. Adicionar $80 \mu \mathrm{l}$ de Detection Antibody em todos os wells. Para um melhor resultado todas as adições devem ocorrer dentro de 1 hora. Cobrir a placa com o papel adesivo e incubá-la a temperatura ambiente por 2 horas em um shaker de placas em rotação moderada, de 400 a 500 rpm.

9. Remover o adesivo e descartar a solução. Bater a placa invertida para retirar o excesso de solução de cada well.

10. Lavar os wells 3 vezes com Wash Buffer diluído, $300 \mathrm{ml}$ por well por lavagem. Descartar a solução e bater a placa sobre papel toalha para remover toda a solução, após cada lavagem. 
11. Adicionar $100 \mu \mathrm{l}$ de Enzyme Solution em cada well. Cobrir a placa com o adesivo e incubá-la com rotação moderada a temperature ambiente por 30 minutos.

12. Remover o adesivo e descartar a solução da placa. Bater a placa invertida para retirar o excesso de solução de cada well.

13. Lavar cada well 6 vezes com Wash Buffer diluído, $300 \mu$ por well por lavagem.

Descartar a solução e bater a placa sobre papel toalha para remover toda a solução, após cada lavagem.

14. Adicionar $100 \mu \mathrm{l}$ de Substrate Solution em cada well, cobrir a placa com o adesivo e incubá-la com rotação moderada por aproximadamente 10 a 15 minutos. A coloração azul deverá ser formada nos wells dos padrões de Insulina com intensidade proporcional a concentração de Insulina.

NOTA: Esteja ciente que a coloração pode aparecer mais rapidamente ou demoradamente que o tempo de incubação recomendado dependendo da temperatura do ambiente. Monitorar visualmente a formação da cor para otimizar o tempo de incubação. A formação da cor pode ser monitorada usando um filtro 370 nm, se disponível no espectofotometro. Quando a absorbância está entre 1.2 e 1.8 a $370 \mathrm{~nm}$, a Stop Solution pode ser adicionada para terminar a formação da cor.

15. Remover o adesivo e adicionar $100 \mu \mathrm{l}$ de Stop Solution [Cuidado: Solução Corrosiva] e misturar com a mão. A cor azul deverá se tornar amarela após a acidificação. Ler na absorbância de 450nm e 590nm dentro de 5 minutes e verificar se não existe bolhas de ar em nenhum well. Registre a diferença das unidades de absorbância. 


\begin{abstract}
Ensaio do Cometa - Preparo de Soluções
Solução de Lise (Estoque)

2,5 M - NaCL -------------- 146,1 g

100 mM - EDTA ------------------- 37,2 g

$10 \mathrm{mM}$ - Tris -------------------- 1,2 g
\end{abstract}

ANEXO 04

Obs: Ajustar o $\mathrm{pH}$ para 10, antes de colocar o N-Lauroyl-Sarcosine.

Completar para $1000 \mathrm{ml}$ com $\mathrm{H}_{2} \mathrm{O}$ destilada. ${ }^{*} \mathrm{~N}$-lauroyl-Sarcosine a $1 \%-10 \mathrm{~g}$

Conservação: Temperatura ambiente, abrigada da luz.

Solução de Lise (Uso)

Triton X - 100 ------------------- 1 ml

DMSO ----------------------------- 10 ml

Completar para $100 \mathrm{ml}$ com solução de Lise estoque.

Obs: Essa solução deve ser feita na hora do uso. Deve ser colocada na geladeira até atingir $4^{\circ} \mathrm{C}$, aproximadamente duas horas antes do uso.

Solução de EDTA (A) (Embrulhar com papel alumínio)

EDTA $14,89 \mathrm{~g}$

$\mathrm{H}_{2} \mathrm{O}$ destilada $200 \mathrm{ml}$

Obs: $\mathrm{O}$ pH deve ser ajustado para 10.

Conservação: Temperatura ambiente.

Solução de $\mathrm{NaOH}(\mathrm{B})$

$\mathrm{NaOH}$ $200 \mathrm{~g}$

$\mathrm{H}_{2} \mathrm{O}$ destilada $500 \mathrm{ml}$

Conservação: Temperatura ambiente, abrigada da luz. 


\section{Solução de Eletroforese}

Deve-se fazer separadas as soluções: A (EDTA) e B (NaOH).

Reagir cinco (5) $\mathrm{ml}$ de solução A e trinta (30) $\mathrm{ml}$ de solução $\mathrm{B}$, completando para $1000 \mathrm{ml}$ com $\mathrm{H}_{2} \mathrm{O}$ destilada. $\mathrm{O} \mathrm{pH}$ deve ser ajustado para 13.

\section{Solução de Neutralização}

\section{0,4 M Tris ------------------- 48,5 g}

Completar para $1000 \mathrm{ml}$ de $\mathrm{H}_{2} \mathrm{O}$ destilada.

Obs: $\mathrm{O}$ pH deve ser ajustado para 7,5.

Conservação: Temperatura ambiente ou geladeira, abrigada da luz.

\section{Agarose - Ponto de Fusão Normal}

Agarose PFN ------------------- $300 \mathrm{mg}(0,3 \mathrm{~g})$

PBS (Livre de $\mathrm{Ca}^{++}$e $\left.\mathrm{Mg}^{++}\right)$----- $20 \mathrm{ml}(20 \mathrm{ml})$

\section{Agarose - Low Melting Point (Baixo Ponto de fusão)}

Agarose LMP ---------------------- $100 \mathrm{mg}(0,1 \mathrm{~g})$

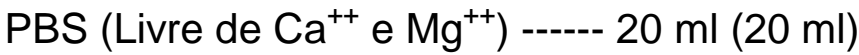

\section{Preparação das lâminas - Gel Primeira Camada}

01. Lavar as lâminas (não é necessário)

02. Diluir a Agarose Ponto de Fusão Normal, deixando-a ferver de duas a três vezes no microondas.

03. Colocar o gel já diluído no banho Maria à $60^{\circ} \mathrm{C}$.

04. Com o auxílio de uma pinça, mergulhar as lâminas limpas no gel sem deixar escorrer.

05. Colocá-las na posição horizontal em frente a um aquecedor, deixando-as secar por algumas horas.

Conservação: Geladeira a $4^{\circ} \mathrm{C}$ ou temperatura ambiente. 


\section{Isolamento de Linfócito}

01. Colocar $2 \mathrm{ml}$ de PBS em tubo falcon de $15 \mathrm{ml}$.

02. Misturar $2 \mathrm{ml}$ de sangue com PBS descrito anteriormente.

03. Em outro tubo falcon colocar $3 \mathrm{ml}$ de Ficol.

04. Pegar o homogeneizado (Sangue + PBS) e colocar cuidadosamente sobre o Ficol, sem misturar (encostar a pipeta na parede do tubo).

05. Centrifugar 30 minutos à 2500 rpm (enquanto isso adicione $4 \mathrm{ml}$ de PBS em outro tubo falcon.

06.Após a centrifugação é formado três fases, retirar o halo branco que é o Linfócito.

07. Centrifugar por 15 minutos à 1.500 rpm

08. Retirar o sobrenadante e deixar 0,5 homogeneizar.

Obs: Linfócitos estáveis por 24 horas à $4^{\circ} \mathrm{C}$.

\section{Congelamento de Linfócitos}

- Para $500 \mu$ l de Linfócito

$50 \%$ de RPMI- $500 \mu \mathrm{l}$

$40 \%$ de Soro Fetal Bovino- $400 \mu l$

$10 \%$ de DMSO- $100 \mu \mathrm{l}$

OBS: Seguir exatamente essa ordem na pipetagem (RPMI, Soro Fetal Bovino, DMSO), misturar em tubo criogênico sobre gelo.

Guardar por 24horas no -80 e passar para o Nitrogênio Líquido.

\section{Descongelamento do Linfócito}

Colocar o tubo criogênico em Banho Maria à $37^{\circ} \mathrm{C}$, deixar quase descongelar (não totalmente), acrescentar $10 \mathrm{ml}$ de PBS e centrifugar 10 minutos à $3.000 \mathrm{rpm}$ à $4^{\circ} \mathrm{C}$. Retirar o sobrenadante e deixar $500 \mu$ l e homogeneizar. 


\section{Ensaio do Cometa}

01. Preparar a solução de lise (uso), duas horas (2h) antes do uso ou até chegar a $4^{\circ} \mathrm{C}$.

02. Diluir a agarose Baixo Ponto de Fusão.

03. Aquecê-la no microondas sem deixar ferver.

04 . Transferí-la para banho-maria à $37^{\circ} \mathrm{C}$.

05. Apagar todas as luzes do laboratório.

06. Coletar $5 \mu$ l de sangue total ou $10 \mu$ l de linfócitos e transferí-lo para um microtubo tipo eppendorf.

07. Pipetar $100 \mu \mathrm{l}$ ou $120 \mu \mathrm{l}$ de agarose LMP, homogenizar junto com o linfócito, respectivamente.

08. Pingar lentamente a mistura feita sobre a lâmina preparada com agarose ponto de fusão normal.

09. Colocar uma lamínula grande (24x60), soltando-a lentamente sobre a lâmina.

10. Deixar na geladeira por 5 minutos.

11. Retirar cuidadosamente a lamínula.

12. Mergulhar a lâmina na solução de lise (uso) recém preparada.

OBS: A cuba com solução de lise deve estar coberta com papel alumínio para proteger da luz.

Montagem das lâminas para indução do Dano e Avaliação do Sistema Reparo.

Solução A- 11,5 $\mu$ l de H2O2 (30\% Merk) em $1 \mathrm{ml}$ de água destilada.

Solução B- $10 \mu l$ de Solução A + $1 \mathrm{ml}$ de PBS, homogeneizar.

Solução C- $100 \mu$ l de solução B e $900 \mu$ le PBS, homogeneizar.

Colocar em eppendorf $200 \mu$ l de linfócito e 100 de Solução C, homogeneizar.

- Incubar o eppendorf por 30 minutos no gelo. 


\section{Montagem das Lâminas de $\mathrm{H} 2 \mathrm{O} 2$}

01. Pipetar $120 \mu \mathrm{l}$ de agarose Low Melting e $10 \mu \mathrm{l}$ do linfócito (que estava encubado);

02. Pingar lentamente sobre a lâmina a mistura;

03. Colocar a lamínula $(24 \times 60)$ sobre a lâmina;

04. Deixar na geladeira por 5 minutos

05. Colocar as lâminas na solução de Lise (uso) recém preparada por 24horas na geladeira.

\section{Montagem das Lâminas de Reparo}

01. Colocar $1 \mathrm{ml}$ de PBS na mistura restante do eppendorf (encubado);

02. Centrifugar á 4 minutos, $2.000 \mathrm{rpm}, 4^{\circ} \mathrm{C}$;

03. Retirar $1 \mathrm{ml}$ de sobrenadante e adicionar novamente $1 \mathrm{ml}$ de PBS, homogeneizar;

04. Centrifugar novamente á 4 minutos, $2.000 \mathrm{rpm}, 4^{\circ} \mathrm{C}$;

06. Retirar $1 \mathrm{ml}$ de sobrenadante e adicionar novamente $1 \mathrm{ml}$ de PBS e homogeneizar, colocar na estufa a $37^{\circ} \mathrm{C}$, por 30 minutos.

07. Pipetar $120 \mu$ l de agarose Low Melting e $10 \mu$ l do linfócito (que estava na estufa a $\left.37^{\circ} \mathrm{C}\right)$;

08. Pingar lentamente sobre a lâmina a mistura;

09. Colocar a lamínula $(24 \times 60)$ sobre a lâmina;

10. Deixar na geladeira por 5 minutos

11. Colocar as lâminas na solução de Lise (uso) recém preparada por 24horas na geladeira.

\section{Eletroforese}

01. Preparar a solução Tampão de Eletroforese, esperar chegar a $4^{\circ} \mathrm{C}$.

02. Envolver a cuba de eletroforese num banho de gelo, mantendo-a a $4^{\circ} \mathrm{C}$.

03. Retirar as lâminas da solução de lise, lavá-las com PBS por 5minutos e colocálas na cuba de eletroforese.

04. Colocar a solução tampão de eletroforese até cobrir as lâminas. 
05. Deixar as lâminas na cuba descansando por 40 minutos.

06. Programar a fonte de eletroforese com:

- $25 \mathrm{v}$

- 30 minutos

- Manter a mili amperagem - 300

07. Retirar cuidadosamente as lâminas da cuba e colocá-las em um trilho de coloração.

08. Lavá-las cuidadosamente com solução de neutralização, por 15 minutos.

09. Mergulhar as lâminas em Etanol 100\% para fixação.

10. Deixar secar a temperatura ambiente.

OBS: A mili amperagem e a potência serão reguladas com a quantidade de solução de eletroforese colocada na cuba.

Padronizar qual lado será deixado para o pólo negativo para que os cometas não corram de lados opostos.

As lâminas podem ser conservadas em temperatura ambiente ou geladeira.

Se for fazer experimento com dano oxidativo, descanso de 40 minutos e corrida de 30 minutos.

\section{Coloração}

01. Para coloração das lâminas, utilizar $50 \mu$ de Sybr Gold (1x).

02. Cobrir com uma lamínula grande $(24 \times 60)$.

03. As lâminas devem ser lidas imediatamente após a coloração.

04. Ao retirar as lamínulas da lâmina, mergulha-las em etanol $100 \%$.

OBS: Se for preciso reanalisar a lâmina, pode ser repetido o procedimento de coloração, sem perder a qualidade da análise.

\section{Análise das lâminas}

As lâminas são analisadas com um microscópio de fluorescência, que permite a visualização das seguintes imagens microscópicas: com contorno circular (sem danos no DNA) ou estruturas em forma de "cometa" (com danos no DNA). A 
extensão de cada imagem significa a distância de migração da fita de DNA danificada, que foi classificada segundo Singh e col. (1988); Pool-Zobel e col.(1994) Speit e col.(1995). As células foram classificadas em cinco categorias (0-4) correspondente às seguintes quantidades de danos na cauda do DNA.

$0 \Rightarrow$ sem danos $(<5 \%)$

$1 \Rightarrow$ baixo nível de danos (5-20\%)

$2 \Rightarrow$ médio nível de danos (20-40\%)

$3 \Rightarrow$ alto nível de danos (40-95\%)

$4 \Rightarrow$ dano total $(>95 \%)$

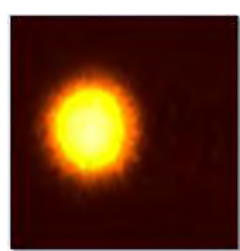

0

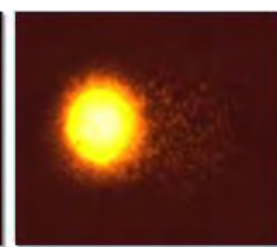

1

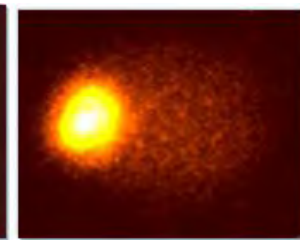

2

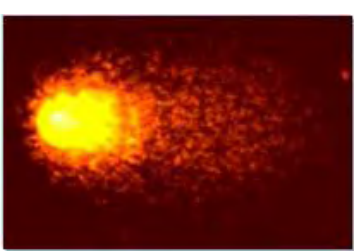

3

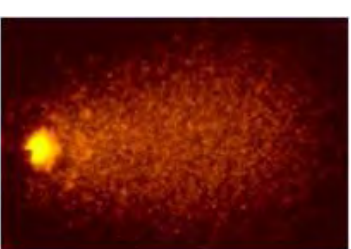

4 


\begin{abstract}
ANEXO 05
Composição das dietas (padrão e hiperlipídica)

A ração padrão RC Focus 1765 foi composta pelos seguintes ingredientes: fosfato bicálcico, óleo de soja degomado, cloreto de sódio, milho moído, aditivo antioxidante, farelo de soja, farelo de trigo, farinha de carne e ossos, farinha de peixe, suplemento mineral e vitamínico. As quatro rações hiperlipídicas $\mathrm{RC}$ Focus 2413, 2414, 2415 e 2416 apresentaram a mesma composição nutricional, com exceção dos aditivos flavorizantes, queijo, bacon, chocolate ou baunilha, respectivamente; as rações foram constituídas de cloreto de sódio, caseína, soro de leite em pó, concentrado protéico de soja, milho integral moído, farinha de bolacha, fosfato bicálcico, carbonato de cálcio, óleo de milho, aditivos emulsificante e antioxidante, suplemento mineral e vitamínico.

A composição de macro e micronutrientes das rações padrão e hiperlipídica, mensurada pela empresa Agroceres $^{\circledR}$, Rio Claro, São Paulo, Brasil, está apresentada no Tabela 1. Os perfis de aminoácidos, carboidratos e ácidos graxos, avaliados no Laboratório de Bioquímica de Microrganismos e Plantas do Departamento de Tecnologia - Faculdade de Ciências Agrárias e Veterinárias, UNESP, Jaboticabal, SP, Brasil, estão apresentado nos Quadros 1, 2 e 3, respectivamente.
\end{abstract}


Quadro 1 - Composição dos macro e micronutrientes das rações (\%)

\begin{tabular}{lcc}
\hline & \multicolumn{2}{c}{ Rações } \\
\cline { 2 - 3 } Componentes & Padrão & Hiperlipídica \\
\hline Proteína & 22,0 & 20,0 \\
Carboidrato & 42,7 & 26,4 \\
Gordura & 4,0 & 20,0 \\
Vitaminas e Minerais & 11,3 & 12,1 \\
Fibras & 8,0 & 9,0 \\
Umidade & 12,0 & 12,5 \\
Calorias (Kcal/g) & 2,95 & 3,65 \\
\% Calorias da proteína & 29,8 & 21,9 \\
\% Calorias do carboidrato & 57,9 & 28,9 \\
\% Calorias da gordura & 12,3 & 49,2 \\
\hline
\end{tabular}

Quadro 2- Perfil de carboidratos das rações (\%)

\begin{tabular}{lcc}
\hline & \multicolumn{2}{c}{ Rações } \\
\cline { 2 - 3 } Carboidratos & Padrão & Hiperlipídica \\
\hline Raffinose & 1,74 & 0,81 \\
Maltose & 1,07 & 1,60 \\
Glicose Livre & 0,82 & 1,63 \\
Glicose & 46,58 & 42,37 \\
Frutose Livre & 0,62 & 0,96 \\
Frutose & 20,93 & 16,46 \\
Sacarose & 8,83 & 11,57 \\
Lactose & 0,65 & 4,48 \\
Fucose & 0,17 & 0,15 \\
Arabinose & 5,55 & 6,78 \\
Galactose & 4,55 & 6,08 \\
Xilose & 5,47 & 4,27 \\
Rhamnose & 0,22 & 0,26 \\
Manose & 2,80 & 2,58 \\
\hline
\end{tabular}


Quadro 3- Perfil de aminoácidos das rações (\%)

\begin{tabular}{|c|c|c|}
\hline \multirow[b]{2}{*}{ Aminoácidos } & \multicolumn{2}{|c|}{ Rações } \\
\hline & Padrão & Hiperlipídica \\
\hline Ácido Aspártico & 10,81 & 9,92 \\
\hline Ácido Glutâmico & 20,12 & 18,99 \\
\hline Serina & 5,23 & 5,06 \\
\hline Glicina & 4,48 & 4,32 \\
\hline Histidina & 2,50 & 2,43 \\
\hline Arginina & 7,47 & 7,07 \\
\hline Treonina & 3,38 & 4,01 \\
\hline Alanina & 4,53 & 4,69 \\
\hline Prolina & 5,93 & 5,80 \\
\hline Tirosina & 3,34 & 3,48 \\
\hline Valina & 5,05 & 5,33 \\
\hline Metionina & 1,89 & 2,43 \\
\hline Cistina & 1,63 & 1,85 \\
\hline Isoleucina & 4,22 & 4,38 \\
\hline Leucina & 7,78 & 7,96 \\
\hline Fenilalanina & 5,01 & 5,01 \\
\hline Lisina & 5,62 & 6,59 \\
\hline Triptofano & 1,01 & 0,68 \\
\hline
\end{tabular}


Quadro 4- Perfil de ácidos graxos saturados e insaturados das rações (\%)

\begin{tabular}{lcc}
\hline & \multicolumn{2}{c}{ Rações } \\
\cline { 2 - 3 } Ácidos graxos & Padrão & Hiperlipídica \\
\hline Capróico (c6:0) & 0,00 & 0,02 \\
Caprílico (c8:0) & 0,03 & 0,03 \\
Cáprico (c10:0) & 0,02 & 0,05 \\
Láurico (c12:0) & 0,33 & 0,25 \\
Mirístico (c14:0) & 0,30 & 0,33 \\
Palmítico (c16:0) & 16,56 & 15,09 \\
Heptadecanóico (c17:0) & 0,02 & 0,08 \\
Esteárico (c18:0) & 3,90 & 4,36 \\
Palmitoléico (c16:1) & 0,06 & 0,15 \\
Oléico (c18:1n9c) & 27,96 & 37,94 \\
Linoléico (c18:2n6c) & 47,10 & 40,83 \\
a-Linolênico (c18:3n3c) & 3,72 & 0,87 \\
Ácidos Graxos Saturados & 21,16 & 20,21 \\
Ácidos Graxos Insaturados & 78,84 & 79,79 \\
\hline
\end{tabular}

